\title{
REVIEW
}

\section{Dendritic Spine Hypoplasticity and Downregulation of Reelin and GABAergic Tone in Schizophrenia Vulnerability}

\author{
Erminio Costa, J ohn Davis, Dennis R. Grayson, \\ Alessandro Guidotti, George D. Pappas, and Christine Pesold \\ Psychiatric Institute, Department of Psychiatry, University of Illinois at Chicago, \\ Chicago, Illinois 60612
}

Received November 7, 2000; revised March 12, 2001; accepted for publication August 7, 2001

\begin{abstract}
In this review, we will first present a brief overview of the current understanding of: (a) the biology of reelin; (b) the putative reelin signaling pathways via integrin receptor stimulation; (c) the cytosolic adapter protein DAB 1, which appears to be operative in the transduction of reelin's pleiotropic actions in embryonic, adolescent, and adult brain; (d) the regulation of GABAergic function, including some aspects of GABAergic system development; and (e) dendritic spine function and its role in the regulation of synaptic plasticity. We argue that a downregulation of reelin expression occurring in prefrontal cortex and in every brain structure of schizophrenia patients so far studied may be associated with a decrease in dendritic spine expression that in turn may provide an important reduction of cortical function as documented by the downregulation of glutamic acid decarboxylase ${ }_{67}$ $\left(G A D_{67}\right)$ expression, which might be secondary to a reduction of GABAergic axon terminals. This hypothesis is supported by a genetic mouse model of reelin haploinsufficiency that replicates the above-described dendritic and presynaptic GABAergic defects documented in schizophrenia brains. o 2001 Academic Press
\end{abstract}

Key Words: reelin; schizophrenia; bipolar disorder; psychosis; dendritic spines; GAD 67 ; reeler heterozygote; integrin.

\section{INTRODUCTION}

There is a confluence of evidence suggesting that genetic neurodevelopmental abnormalities may be a component of the etiology of schizophrenia (Andreasen et al., 1986; Jones \& Murray, 1991; Bloom, 1993; Weinberger \& Lipska, 1995; Woods, 1998). Here we present recently acquired information indicating that a downregulation of the reelin gene may be an example of a genetic abnormality that may be considered a factor for schizophrenia vulnerability.

As a group, schizophrenia patients exhibit a loss of brain tissue leading to an increase in cerebral ventricular volume and to an enlargement in the fluid space that surrounds the brain (Johnstone et al., 1976; Bertolino et al., 1998; Weinberger et al., 1986; McCarley et al., 1999; Altshuler et al., 2000; Crespo-Facorro et al., 2000; Falkai et al., 2000). This ventricular enlargement is believed to have started before the onset of any clinical manifestation of the disease, but studies directed at documenting such a succession of events are not yet available. It is, however, very likely that the process causing brain tissue loss in schizophrenia is not related to neurodegeneration because the gliosis that normally accompanies cell necrosis is virtually absent (Akbarian et al., 1995; Selemon \& Goldman-Rakic, 1999).

Recent reports (Selemon \& Goldman-Rakic, 1999) have described a reduction of interneuronal neuropil and an apparent increase in neuronal packing density in the prefrontal cortex (PFC) and other brain struc- 
TABLE 1

Summary of Anatomical Abnormalities in the Brains of Schizophrenic Patients and the Heterozygote Reeler Mouse

Heterozygote reeler mouse

$\uparrow$ Dilation of lateral cerebral ventricles (Johnstone et al. 1976;

Weinberger et al., 1995)

$\uparrow$ Cell packing density in frontal cortex (Selomon \& GoldmanRakic, 1999)

$\downarrow$ Neuropil density in frontal cortex (Selomon \& Goldman-Rakic, 1999)

$\downarrow$ Dendritic spine density on layer III pyramidal cells (Glantz \& Lewis, 2000)

Altered distribution of NADPH-diaphorase positive cells

(Akbarian et al., 1993)

$\downarrow \mathrm{GAD}_{67}$ mRNA and protein in frontal cortex (Impagnatiello et al. 1998; Guidotti et al., 2000)

$\downarrow \mathrm{GAD}_{67}$ mRNA positive cells in frontal cortex (Akbarian et al., 1995; Volk et al., 2000)

$\downarrow$ Reelin mRNA and protein in frontal cortex (Impagnatiello et al., 1998; Guidotti et al., 2000)

$\downarrow$ Number of reelin-positive cells (Impagnatiello et al., 1998;

Guidotti et al., 2000)

Disruption of physiological correlation between reelin and $\mathrm{GAD}_{67}$ (Guidotti et al., 2000)
Not yet quantified

$\uparrow$ Cortical neuronal packing density (Pesold et al., 1999a)

$\downarrow$ Cortical neuropil density (Pesold et al., 1999a)

$\downarrow$ Dendritic spine density on layer III pyramidal cells (Costa et al., 2000)

Altered distribution of NADPH-diaphorase cells (Tueting et al., 1999)

$\downarrow \mathrm{GAD}_{67}$ mRNA and protein levels (Pesold et al., 1999a)

$\downarrow$ Number of $\mathrm{GAD}_{67}$-positive cells in frontal cortex (Pesold et al., 1999a)

$\downarrow$ Reelin protein and mRNA levels (Tueting et al., 1999)

$\downarrow$ Number of reelin-positive cells (Pesold et al., 1999a)

Loss of correlation between reelin and $\mathrm{GAD}_{67}$ levels (Carbonni et al., 2000) tures of schizophrenia patients. Transcripts encoding proteins involved in the regulation of presynaptic function were found to be decreased in the PFC of schizophrenia patients, presumably reflecting a reduction of GABAergic or glutamatergic axon terminals impinging on dendrites of pyramidal cortical neurons (Mirnics et al., 2000). Other reports also suggest that a reduction in the dendritic spine density in schizophrenia patients may be part of the above-mentioned cortical neuropil hypoplasticity (Garey et al., 1998; Glantz \& Lewis, 2000; Rosoklija et al., 2000). This hypoplasticity prompted us to consider whether a downregulation in the expression of the reelin gene occurring during the second trimester of pregnancy could trigger secondary anomalies in corticogenesis leading to interneuronal neuropil hypoplasticity at a later time.

Several studies have revealed that reelin is not exclusively a neurodevelopmental gene but continues to be expressed in the brain of adult rats, nonhuman primates, and humans (Alcantara et al., 1998; Impagnatiello et al., 1998; Pesold et al., 1998, 1999b; Fatemi et al., 2000; Guidotti et al., 2000; Rodriguez et al., 2000). We first determined that in adult mammalian brain, reelin is an extracellular matrix (ECM) protein secreted by specific GABAergic interneurons from the telencephalon and hippocampus (Pesold et al., 1998, 1999b; Rodriguez et al., 2000). We also know from Benes's pioneering work (Benes et al., 1992) and from the contributions of Jones and colleagues (Akbarian et al., 1995) that presynaptic GABAergic function is probably downregulated in schizophrenia. The neuroanatomical and neurochemical abnormalities of neocortical GABAergic neurons impinging on pyramidal neurons in postmortem schizophrenia brains can be summarized as follows: (see also Table 1): (1) a decrease in GABA release and uptake (Sherman et al., 1991; Simpson et al., 1998; Reynolds et al., 1990); (2) an increase of $\mathrm{GABA}_{\mathrm{A}}$ receptor density measured by $\left[{ }^{3} \mathrm{H}\right]$-muscimol binding, particularly in layer II of the PFC and in superficial layers of other adjacent cortical areas (Benes et al., 1992; Benes, 2000); (3) an increase in the expression of the $\alpha_{1} \mathrm{GABA}_{\mathrm{A}}$ receptor subunit mRNA in the PFC (Impagnatiello et al., 1998); (4) a dorsolateral PFC decrease of presynaptic GABA transporter1-positive cartridges in GABAergic axon terminals of chandelier cells impinging bilaterally on the initial segments of pyramidal axons (Woo et al., 1998), and (5) decreased glutamic acid decarboxylase ${ }_{67}$ $\left(\mathrm{GAD}_{67}\right)$ expression (Akbarian et al., 1995; Impagnatiello et al., 1998; Volk et al., 2000; Benes, 2000; Bunney \& Bunney, 2000; Guidotti et al., 2000). This enzyme is one of the two molecular forms of GAD expressed in GABAergic neurons, the other being GAD $_{65}$ (Soghomonian and Martin, 1998).

In addition to replicating these findings in brains of schizophrenia patients, we extended many of these findings to the brains of patients with bipolar disorder with mania (Guidotti et al., 2000). We also showed that 
$\mathrm{GAD}_{67}$, but not $\mathrm{GAD}_{65}$, is downregulated in postmortem brains of schizophrenia and in bipolar disorder patients with psychosis (Guidotti et al., 2000). Finally, we found that reelin and $\mathrm{GAD}_{67}$ expression (mRNA and protein) was not downregulated in unipolar depression or bipolar disorder without psychosis (Guidotti et al., 2000).

The origins of the above-mentioned neurochemical and histological changes in schizophrenia and bipolar disorder with mania are unknown but a vulnerability depending on the deficiency of reelin expression will be proposed and analyzed in the present overview. In addition, using genetic models of reelin and $\mathrm{GAD}_{67}$ haploinsufficiency, we will analyze whether a deficit in the pleiotropic actions of reelin can account for psychosis vulnerability and/or for the variability in symptomatology expressed during the progression of schizophrenia and bipolar disorder with mania by most but not all patients. We need to add that the reelin haploinsufficient heterozygous reeler mouse (HRM) not only fails to express the phenotype of the reelin null mutant but also expresses a downregulation of $\mathrm{GAD}_{67}$ (Tueting et al., 1999; Liu et al., 2001). Interestingly, the brains of schizophrenia patients and those of the HRM model show many similar neuroanatomical and neurochemical abnormalities (Pesold et al., 1999a; Liu et al., 2001), including a downregulation of the interneuronal neuropil density with a reduction in the expression of pyramidal dendritic spines in the telencephalon (Garey et al., 1998; Liu et al., 2001) associated with sensory gating abnormalities (see Table 1 and Tueting et al., 1999). Finally, in the above-mentioned psychiatric disorders (Guidotti et al., 2001) and in the HRM model (Liu et al., 2001), the levels of brain reelin and $\mathrm{GAD}_{67}$ are not correlated as they are in nonpsychiatric subjects, in unipolar depression, and in the wild-type background (see Table 1) (Guidotti et al., 2000, and Liu et al., 2001). Collectively, these data allow us to speculate that reelin and GABAergic function downregulation might act as putative vulnerability factors in the etiopathology of schizophrenia and probably of other psychiatric disorders, including bipolar disorders with mania.

\section{BACKGROUND INFORMATION ON REELIN}

For the reader's convenience, we present a brief background overview of the present understanding of reelin function, including a description of its pleiotropic functions in neuronal positioning (during embryonic development), regulation of GABAergic trans- mission, dendritic spine expression, and plasticity (in mature brain).

\section{Reelin in Embryogenesis}

Normal corticogenesis. Reelin is a protein that is synthesized in the telencephalon by Cajal-Retzius cells and in embryonic cerebellum by external granule cells: both cells secrete this protein into the ECM, probably via a constitutive mechanism (D'Arcangelo et al., 1995; Miyata et al., 1997; Rice \& Curran, 1999; Lambert-Derouvroit \& Goffinet, 1998; Lacor et al., 2000). Reelin includes 3461 amino acid (aa) residues conferring a relative molecular mass of $388 \mathrm{kDa}$ to this protein (Fig. 1). The amino-terminal region of this protein expresses a signal peptide followed by a sequence (aa residues 22-190) with a 25\% homology with the F-spondin. Spondins belong to an ECM protein family contributing, for example, to neurodevelopmental regulation of the extension of spinal cord commissural axons (Klar et al., 1992). The aa residues 230-346 of reelin express a consensus that appears to be operational in its signal transduction (Ogawa et al., 1995; Utsunomiya-Tate et al., 2000) via integrin or cadherin receptors expressed by migrating cortical neuroblasts (Xiao et al., 1991; Staubli et al., 1998; Pinkstaff et al., 1999; Dulabon et al., 2000; Yagi \& Takeichi, 2000). It is likely that reelin homopolymerizes following its secretion into the ECM by specific neurons (i.e., Cajal-Retzius cells in embryonic cortex, external granule cells in embryonic cerebellum). Both this homopolymerization and the cytosolic phosphorylation of DAB1 (for a review on DAB1 see Rice \& Curran, 1999) are inhibited in the presence of the reelin monoclonal allo-antibody termed CR-50, which recognizes a reelin epitope located within aa residues 230-346 (Utsunomiya et al., 2000). According to this report, reelin homopolymerization critically depends on the electrostatic interactions occuring when this protein is dissolved in $0.15 \mathrm{M} \mathrm{NaCl}$ solution. Homopolymerized reelin is partially dissociated by increasing the $\mathrm{NaCl}$ concentrations to $0.5 \mathrm{M}$ and it is completely dissociated at $1 \mathrm{M} \mathrm{NaCl}$. This homopolymerization may be important in decreasing reelin enzymatic degradation during its extracellular transport. Since integrin receptors are stimulated by agonist protein adhesion (Xiao et al., 1991; Staubli et al., 1998), this process may be facilitated by reelin homopolymerization. Using the Congo red binding assay, Utsunomiya and colleagues (2000) found that the reelin epitope recognized by CR-50 antibody at physiological $\mathrm{NaCl}$ concentrations contributes to the formation of a linear soluble homopolymer of reelin. A deletion of the aa residues 

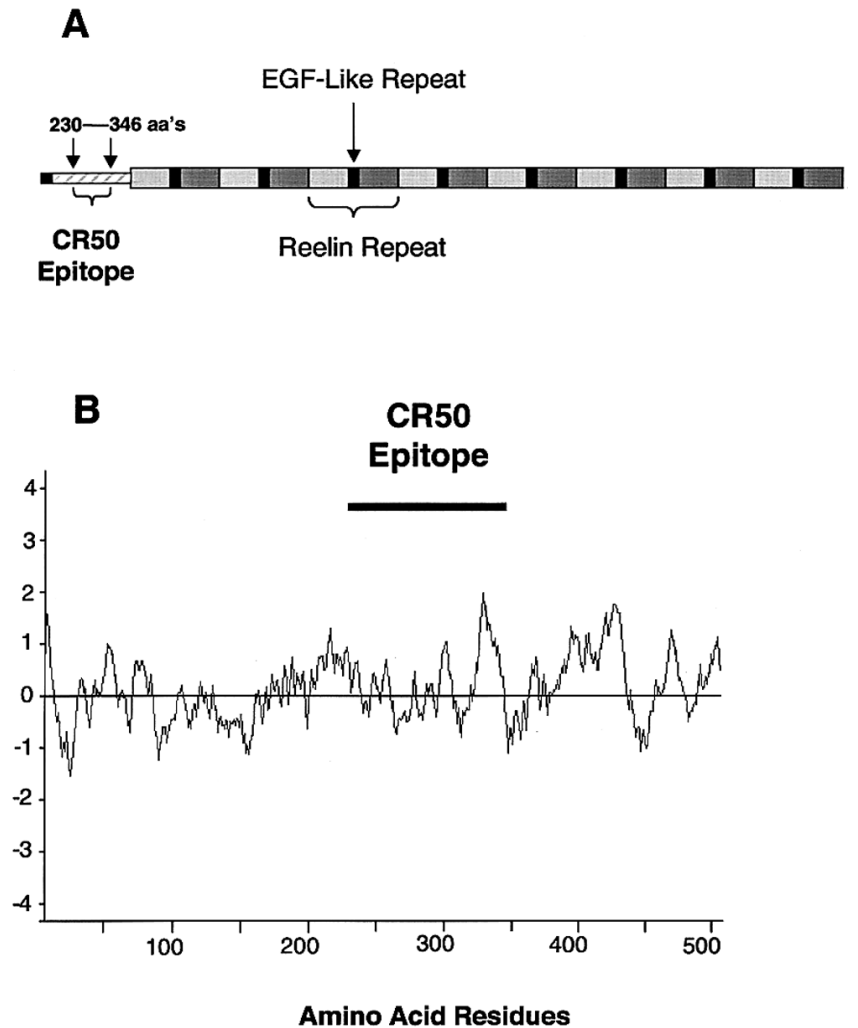

FIG. 1. Reelin protein structure. (A) A linear representation of the reelin protein. The amino terminal signal peptide is depicted in black. The CR50 antibody recognizes an epitope that has been mapped to amino acids 230 through 346 (Utsunomiya et al., 2000). Reelin contains a series of 8 repeats in which each repeat contains an A domain (light gray) and B domain (dark gray). The A and B domains are separated by an EGF-like motif (D'Arcangelo et al., 1995). (B) The hydrophilic profile of the amino-terminal 500 amino acids of reelin. Positive numbers represent stretches of hydrophilic amino acids while negative numbers correlate with stretches of hydrophobic amino acids. The profile was calculated using the Kyte-Doolittle method for displaying hydrophilicity (Kyte \& Doolittle, 1982). The location of the CR50 epitope within this profile is indicated.

containing the epitope recognized by the CR-50 antibody inhibits homopolymerization and reelin-induced cytosolic DAB1 phosphorylation, suggesting that this fragment is important in reelin function (Utsunomiya et al., 2001).

During embryonic corticogenesis of cordates, reelin functions as a key regulator of ordered neuronal alignment and reelin is almost exclusively synthesized and secreted by Cajal-Retzius cells located in the marginal zone of the developing cortex (Fig. 2A) (D'Arcangelo et al., 1995; Ogawa et al., 1995; Lambert de Rouvroit \& Goffinet, 1998). Neurons proliferating in the ventricular zone migrate along radial glia for distances one hundred-fold their cell body length to arrive at their proper final position in the developing cortical plate. The work initiated by His (1891) and Ramon y Cajal (work that can be consulted in the 1955 CSIC edition, see references) and continued by Rakic and Caviness (1995) and many others (for a review see Gleeson and Walsh, 2000) established that cortical neuroblasts and a subpopulation of GABAergic interneuron precursors, both expressing DAB1 (Rice \& Curran, 1999; Pesold et al., 1998), migrate toward the subplate, penetrate this structure, and accumulate below the marginal zone to form the cortical plate, where they organize themselves into the six neuronal layers that ultimately will become an integral part of the adult cortex (Fig. 2A). In rodents, the preplate and cortical subplate are formed at E13-14. When the cortical plate appears, the preplate cells divide into two groups: (a) the marginal zone cells beneath the pial surface that give origin to the Cajal-Retzius cells and (b) the deeper subplate that is penetrated by migrating neuroblasts. Rakic (1995a, 1995b) birth dated migrating neurons and demonstrated that these neurons are layered in the cortical plate in an "inside-out" order. In other words, neurons migrate closer to the marginal zone in an order identical to that of their arrival in the cortical plate.

Altered corticogenesis in mouse and human expressing reelin gene mutations. The discovery that corticogenesis depends on a complex neuronal migration pattern has led to an important revolutionary research trend that has brought about the discovery and study of a number of natural deviations from the norm due to spontaneous genetic mutations (for a review see Uher \& Golden, 2000). The reeler mouse (a null reelin gene mutation) is the best characterized among these mutations, and in addition to a severe cerebellar atrophy, it displays an inversion of the inside-out physiological order of cortical neuroblast position and other important structural abnormalities in neuronal maturation (Rakic, 1995; Rakic \& Caviness, 1995; Lambert-Derouvroit \& Goffinet, 1998).

In humans, there are several brain diseases that originate from a mutation-induced disorder in cortical neuron migration (Uher \& Golden, 2000). It is presently believed that about one third of the most severe forms of epilepsy and a number of mental retardation syndromes originate from abnormalities in corticogenesis (Gleeson \& Walsh, 2000). Recently, a form of autosomal recessive lissencephaly with abnormal cerebral cortical neuronal migration, abnormal axonal connectivity, and cerebellar hypoplasia has been associated with mutations in the reelin gene (Hong et al., 2000). Human subjects with reelin gene mutations ex- 


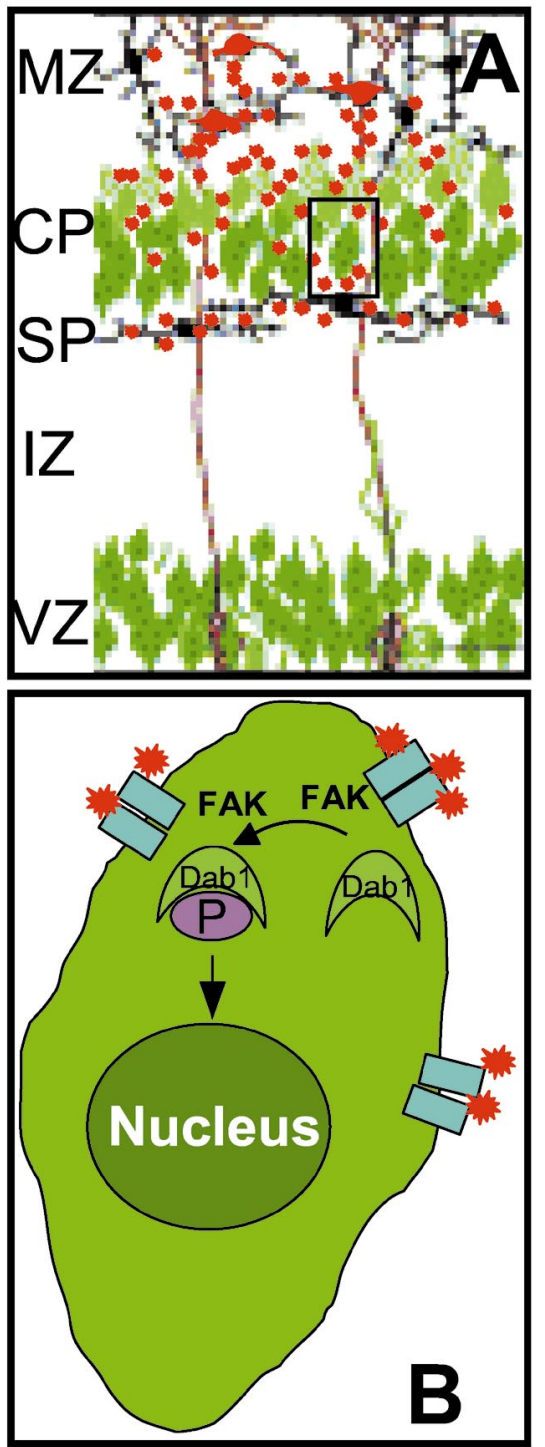

$\square \square$ Integrin Receptor Reelin

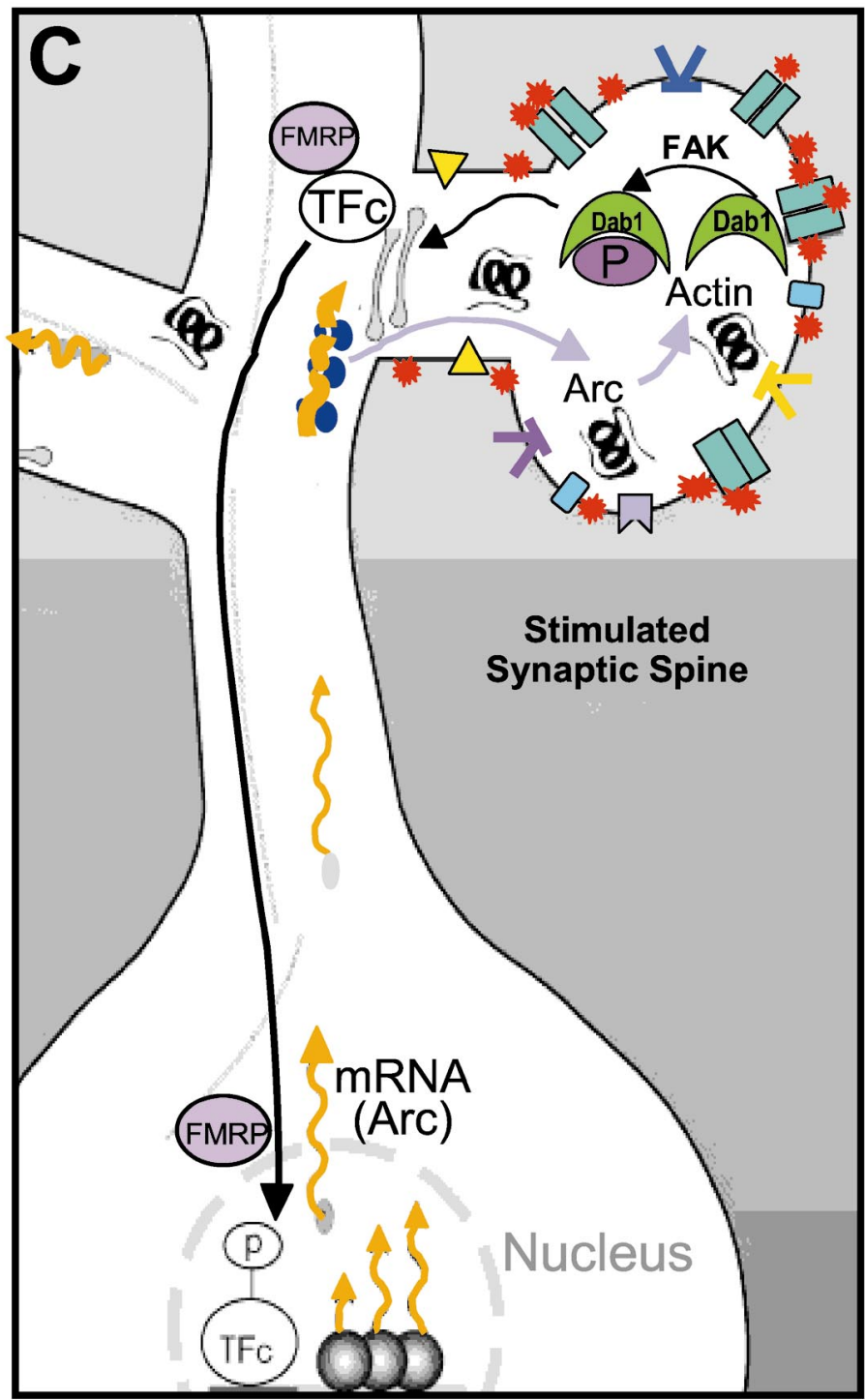

Ribosome @g Protein

mRNA
○ Ionotropic Glu Receptor $\square$ Metabotropic Glu Receptor

$\Longleftarrow$ Spine Apparatus $\triangle G A B A_{A}$ Receptor
FAK
Serotonin Receptor
FMRP Fragile $X$ Protein Focal Adhesion Kinase

1 Dopamine Receptor Arc - Activity Regulated Cytoskeletal-Associated Protein 1 Acetylcholine Receptor (TFC) Transcription Factor

FIG. 2. Schematic representation of the reelin signaling pathway in developing (A and B) and in adult brain (C). (A) Reelin action on neuronal positioning and differentiation in developing brain (modified from Gleeson \& Walsh, 2000). (B) Larger scale of a cortical plate neuron in A. (C) Dendritic spine transcription of resident mRNAs in transynaptically activated synapses (modified from Kuhl \& Skehel, 1998). MZ, marginal zone; CP, cortical plate; SP, subplate; IZ, intermediate zone; VZ, ventricular zone.

press a marked ventricular dilation, mental retardation, and epilepsy and a marked decrease of muscle tone that appears of neurogenic origin. In both the homozygous reelin null mutant subjects affected by lissencephaly, and in the haploinsufficient heterozygous reeler parents that neither show lissencephaly 
nor the extreme ventricular dilation, there are marked signs of mental retardation (Hourihane et al., 1993) that hamper attempts to diagnose psychiatric disorders.

From experiments in mice, the primary defect of the homozygous reelin gene mutation is that the migrating neuroblasts fail to penetrate the subplate; hence they push this plate toward the marginal zone, thereby forming a superplate. Directly or indirectly, reelin contributes to the separation of the marginal zone from the subplate. The failure of neurons to penetrate the subplate, probably due to reelin deficiency, ultimately, with the formation of the superplate, causes an inversion in the direction of neuronal cortical migration from "inside-out" to "outside-in." The lack of reelin deposition in the ECM probably leads to the abnormal maturation, migration, and lack of subplate penetration, which brings about the mispositioning of cortical neuroblasts.

The observation that in mouse embryonic cortical slice cultures, the CR-50 anti-reelin antibody prevents the physiological inside-out distribution of neurons and promotes their outside-in pattern of alignment strongly supports the view that reelin plays a critical role in the penetration of the subplate by migrating neuroblasts, in establishing their normal positioning, maturation, and ultimately, synaptogenesis (Ogawa et al., 1995; Miyata et al., 1997).

Reelin's role on the embryonic sprouting of Purkinje cell dendrites. In mice, during the last days of embryonic cerebellar development (E16-E18) granule neurons that have terminated their migration and association with Bergman glia continue to synthesize and secrete reelin (Miyata et al., 1997). During embryogenesis, the reelin regulation of Purkinje cell positioning is documented by the prevention of their alignment following the addition of the CR-50 antibody (Miyata et al., 1997). In postnatal cerebellum, reelin is secreted by the axon terminals of the cerebellar granule neurons (parallel fibers) in proximity to Purkinje cell dendrites. This protein stimulates the sprouting of Purkinje cell dendrites that express DAB1 (Pesold et al., 1998) and integrin receptors containing the $\alpha_{3}$ subunit (Pesold, unpublished observations). Presumably, the amazing arborization of Purkinje cell dendrites requires the presence of reelin, which presumably stimulates the synthesis of cytoskeletal proteins via activation of DAB1 adapter function. In null reeler mutant mice and homozygous reelin mutant human subjects, there is a strong disturbance in cerebellar development, very likely due to a primary abnormality of Purkinje cell dendritic sprouting. The extreme dendritic hypoplasia that characterizes the histology of the reeler mouse cerebellum offers a most convincing reflection of the important trophic role of reelin on Purkinje cell dendrites. This marked cerebellar hypotrophy is considered a major cause of the ataxia that characterizes the reeling gait of the null mutant reeler phenotype (Miyata et al., 1997; Lambert-Derouvroit \& Goffinet, 1998) and the inability of sit or stand of human subjects with homozygous reelin gene mutations (Hong et al., 2000). It appears that reelin may have a role in the maturation of the neuromuscular system, and this may be a cause for this muscular hypotonia, but this link should be investigated in relation to reelin expression in some cholinergic neurons of the spinal cord anterior horn (Pesold et al., 2000).

The conundrum of reelin signal transduction in embryonic brain. The scrambler and the yotari mice mutations that exhibit a phenotype virtually identical to the reeler mouse express a defect in the biosynthesis of the adapter protein DAB1, the putative cytosolic target of reelin action (Howell et al., 1997; Sheldon et al., 1997). Following DAB1 phosphorylation by a tyrosine kinase (termed focal adhesion kinase-FAK) that is activated by the clustering of integrin receptor subunits following the adhesion of an integrin receptor agonist (Giancotti \& Ruoslahti, 1999)-DAB1 binds and protects the integrity of proteins while it transports them to the nucleus (i.e., soluble tyrosine kinases and transcription factors) and probably also to other functional cellular compartments. The proteins transported by DAB1 promote nuclear gene expression or mRNA translation (Fig. 2B). DAB1 is expressed by neuroblast precursors of pyramidal neurons proliferating in the ventricular zone and migrating toward the preplate while associated with radial glia (Rakic \& Caviness, 1995; Rice \& Curran, 1999). It is presently appreciated that the inhibitory interneurons of the adult cortex include cells generated by two subpopulations of GABAergic neuroblasts; one of which originates in the primordium of the caudate nucleus and the other in the proliferating ventricular epithelium. Tangentially migrating GABAergic neuroblasts originating in the caudate nucleus primordium also express DAB1 (Caruncho $\mathrm{H}$, unpublished observation). This protein appears to contribute to tangential migration of these neuroblasts that allows them to reach their proper final position in the developing neocortex (Rakic, 1995; Haydar et al., 2000; Kaas \& Anton, 2000). In short, several lines of investigation (Howell et al., 1997, Rice \& Curran, 1999) indicate that the DAB1 adapter function critically depends on reelin availability.

Curran and his collaborators (D'Arcangelo et al., 1999) have also contributed to the search for a membrane receptor that mediates the reelin-DAB1 inter- 
action by following a protein-to-protein recognition pattern strategy. Since DAB1 interacts with proteins that express the amino acid consensus motif "NPxY," they suggested that receptors expressing such a consensus are candidates for reelin-mediated signal transduction. They identified the products of two brain receptor genes expressing this motif: apolipoprotein $\mathrm{E}$ receptor 2 (ApoER2) and the very low density lipoprotein receptor (VLDLR), also known as LDLR-related protein with eight ligand repeats (LR8). The knockout of both these genes, but not that of one or the other alone, induces a reeler/yotari/scrambler-like phenotype.

Anton et al., (1999) developed a knockout mouse of the $\alpha_{3}$ subunit of integrin receptors. This knockout mouse expresses a phenotype, comparable to the phenotype of the combined ApoER2 and VLDLR knockout that resembles the null mutant reeler mouse. Using the $\alpha_{3}$ integrin knockout mice, Anton et al. (1999) provided evidence that ECM reelin signal transduction is mediated by integrin receptor subtypes expressing the $\alpha_{3}$ subunit (Dulabon et al., 2000). These integrin receptors establish communication between the ECM and the neuronal cytoskeleton proteins, via a possible reelin-mediated integrin receptor clustering, which may activate the FAK (see Fig. 2B) and which in turn phosphorylates Dab 1. A reeler-like phenotype was also obtained with the knockout of the cyclindependent kinase 5 (cdk5) or of its neuron-specific activator p35 (Gilmore et al., 1998; Kwon \& Tsai, 1998). However, it is not clear whether cdk5 can induce the adapter function of DAB1. Also, a family of cadherinrelated neuronal surface proteins termed CNRs (cadherin-related neuronal receptors) has been identified as a putative receptor mediating the reelin signal transduction cascade (Yagi \& Takeichi, 2000). The cytosolic portion of CNRs associates with Fyn kinase, which is known to phosphorylate DAB1 and may induce its adapter function.

There is an apparent multiplicity of putative receptors mediating reelin signal transduction in embryos. This plethora of receptors may indicate that, as also suggested by Curran (Rice \& Curran, 1999), reelin is essential in corticogenesis but its transduction leading to the phosphorylation of DAB1 with a tyrosine kinase may involve a number of alternative pathways. Taken together, the available evidence favors the model of a reelin-integrin or a CNR receptor pathway as an important but probably not unique pathway operative in rodent and perhaps human embryonic corticogenesis.

\section{Reelin in Adult Brain}

Reelin is located in different types of neurons. Reelin is also synthesized and secreted predominantly by specific GABAergic interneurons in the cortex and hippocampus of adult rodents and primates (Impagnatiello et al., 1998; Pesold et al., 1998, 1999b; Alcantara et al., 1998; Fatemi et al., 2000, Guidotti et al., 2000; Rodriguez et al., 2000). In several structures of adult mammalian brain, reelin is synthesized and secreted by modulatory interneurons, whereas DAB1 is consistently expressed by neurons that are the primary targets of interneurons and usually provide the functional output of that brain structure (Pesold et al., 1998, 1999b; Impagnatiello et al., 1998; Rodriguez et al., 2000). For instance, in various cortical areas and hippocampus, reelin is preferentially expressed and secreted in the ECM by GABAergic interneurons, whereas the DAB1 protein is expressed by glutamatergic pyramidal neurons, which function as the main cortical output and are targets of the action of GABAergic interneurons that secrete reelin in the ECM surrounding dendrites and spines of pyramidal cells (Rodriguez et al., 2000). In contrast, in cerebellum reelin is predominantly synthesized and stored by glutamatergic granular cells, and is secreted by their parallel fiber axon terminals in ECM surrounding the dendrites of GABAergic Purkinje cells, which express DAB1 and function as cerebellar output, innervating the deep cerebellar nuclei (Pesold et al., 1988).

Based on the expression of reelin immunoreactivity to specific antibodies directed at the amino terminus of this protein, we can distinguish at least two sets of GABAergic inhibitory synapses that influence the firing of pyramidal neurons in the neocortex. The first set of afferents project from reelin-immunopositive GABAergic horizontal, double bouquet (bitufted), multipolar, and Martinotti neurons (Pesold et al., 1999 b) to pyramidal neurons, apical or basal dendrites, and their spines (Nieuwenhuys, 1994; Somogyi et al., 1998), where they usually innervate the dendritic spine neck (Fiala \& Harris, 1999). The second set of connections originate from chandelier and basket GABAergic interneurons that innervate the axon initial segment or the pyramidal neuron soma, respectively (Nieuwenhuys, 1994; Somogyi et al., 1998). Apparently these two subtypes of interneurons do not express reelin (Pesold et al., 1998, 1999b).

Specific location of reelin secreted in the extracellular matrix of the neocortex. The presence of diffuse but intense bands of reelin immunoreactivity in cortical neuropil of adult rats, monkeys, and humans appears to be associated with the neuronal secretion of reelin 


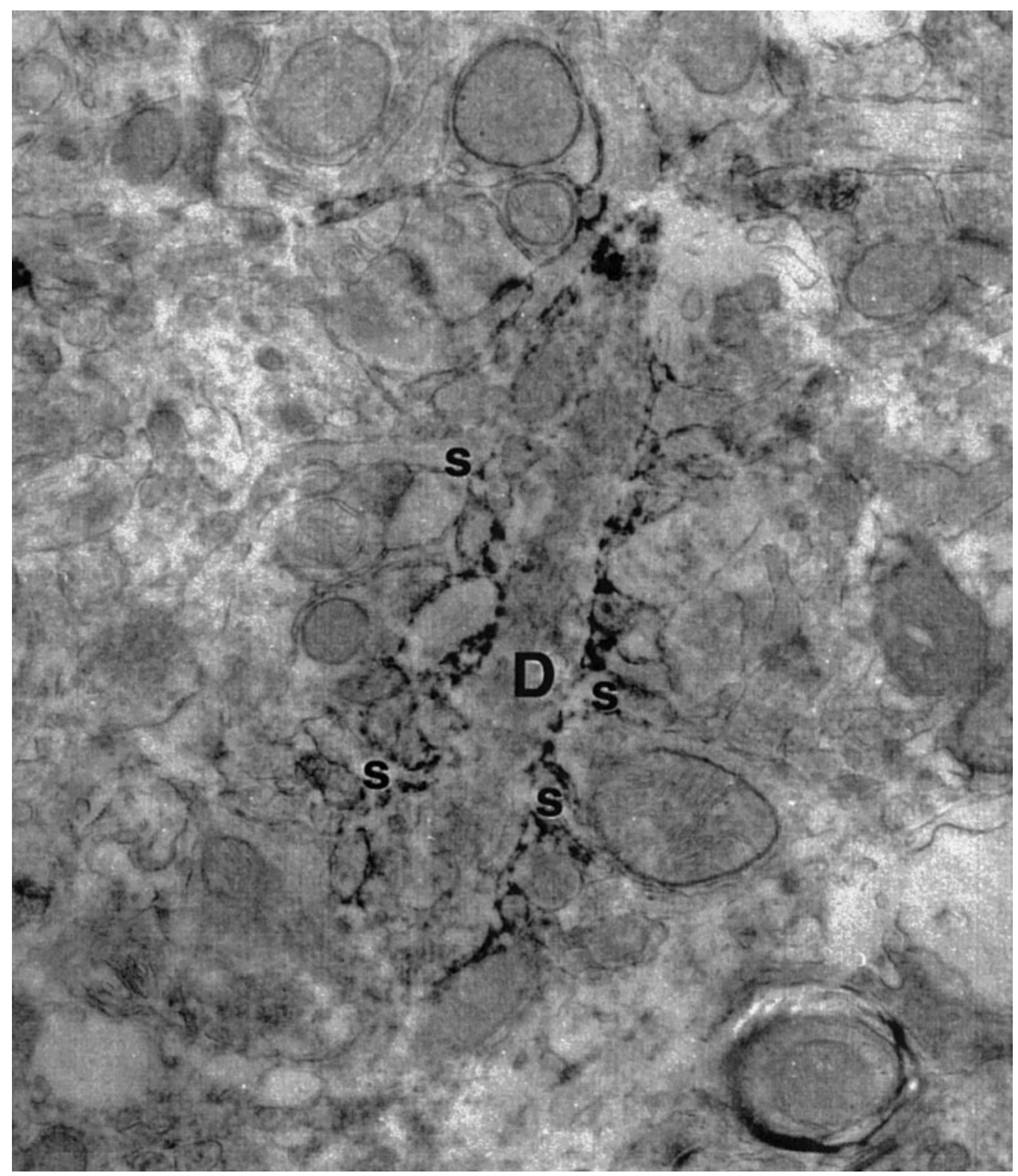

FIG. 3. Electron micrograph of reelin-immunostaining of thin sections taken from layer I-II of the frontal cortex of nonhuman primate brain. Note reelin-immunoreactivity surrounding a dendritic shaft and many of its dendritic spines. D, Dendrite; s, spine. Magnification, $42,000 \times$.

and is consistently detected by light microscopy in neocortex and hippocampus of rodents, nonhuman primates, and humans (Impagnatiello et al., 1998; Guidotti et al., 2000; Pesold et al., 1998, 1999b; Rodriguez et al., 2000). These bands may reflect specific reelin binding to some ECM structures, and are absent or less intense in the brain of patients with schizophrenia or bipolar disorder with mania and in the HRM model. Because electron microscopy studies are required to elucidate the subcellular location of ECM proteins and because it is widely recognized that the electron microscopy of postmortem human brain is limited by a protracted postmortem time interval (Roberts et al., 1996) and by the lack of tissue perfusion with a fixative, we directed our efforts to the electron microscopic investigation of the subcellular location of reelin in the ECM of rodent and nonhuman primate brain perfused during anesthesia (Pesold et al., 1998; Rodriguez et al., 2000).

The electron micrograph in Fig. 3 shows the presence of reelin-like immunoreactivity apparently bound to dendritic shafts and spines of an apical den- 
drite from a pyramidal neuron in the frontal cortex of Patas monkey. The presence of reelin surrounding the synapses located on these dendritic spines (Fig. 3) and the reelin colocalization with the $\alpha_{3}$ subunit of the integrin receptor in postsynaptic dendritic spines (Rodriguez et al., 2000) of adult rat and primate brains clearly suggest that a reelin signal transduction mechanism involving integrin receptors may be present in dendritic spines. We infer that reelin might participate in the plastic modification of these structures. Furthermore, since the DAB1 protein is expressed in the cytosol of dendritic spines of the frontal cortex of Patas monkey (Rodriguez et al., 2000), we suggest that this adapter protein is likely operative in reelin signal transduction in the dendrites of pyramidal neurons.

Based on the available information (Utsunomiya-Tate et al., 2000), we postulate that in the neuropil of adult primate and rodent cortices, reelin adheres to dendrites and spines, presumably as a homopolymeric aggregate. During spine depolarization, reelin adherence to integrin receptors expressed in dendritic spines causes the clustering of integrin or CNR receptor subunits, which in turn activate a FAK that directly or indirectly phosphorylates the cytosolic adapter protein DAB1 (see Fig. 2C). The adapter function of phosphorylated DAB1 may be operative in regulating the dendritic spine cytoskeletal protein synthesis by directly or indirectly activating the translation of dendrite-resident mRNAs (Fig. 2). These mRNAs encode cytoskeletal proteins, such as activityregulated-cytoskeleton-associated protein [Arc] (Steward et al., 1998) or activators of nuclear DNA transcription, such as CAMP-response-element binding protein (CREB), Fos, Jun, fragile $\mathrm{X}$ mental retardation protein (FMRP), CaMKII (calcium/calmodulin kinase II), $\mathrm{GABA}_{\mathrm{A}}$, glutamate, and acetylcholine ionotropic receptor subunits (Kuhl \& Skekel, 1998; Eberwine, 1999; Klintsova \& Greenough, 1999).

\section{DOWNREGULATION OF GAD 67 , REELIN AND DENDRITIC SPINE EXPRESSION IN SCHIZOPHRENIA AND BIPOLAR DISORDER WITH MANIA}

\section{Reelin and $\mathrm{GAD}_{67}$ Downregulation}

An initial study on postmortem brains obtained from different brain banks (Impagnatiello et al., 1998) showed that reelin expression (mRNA and protein) is downregulated in the PFC (Brodmann's areas 10 and 46), temporal cortex, hippocampus, caudate nucleus, and cerebellum of schizophrenia brains (Table 2). In the same study we also found that in temporal cortex (area 22), the
TABLE 2

Reelin mRNA (fmol/ $\mu \mathrm{g}$ total RNA) in Different Areas of Postmortem Brains

\begin{tabular}{lcc}
\hline \multicolumn{1}{c}{ Brain region } & Nonpsychiatric & Schizophrenia \\
\hline Prefrontal cortex & $0.38 \pm 0.020$ & $0.22 \pm 0.018^{* * *}$ \\
Temporal cortex & $0.42 \pm 0.060$ & $0.25 \pm 0.04^{*}$ \\
Cerebellum & $2.3 \pm 0.17$ & $1.4 \pm 0.24^{* *}$ \\
Hippocampus & $0.30 \pm 0.030$ & $0.15 \pm 0.038^{* *}$ \\
Caudate nucleus & $0.080 \pm 0.019$ & $0.023 \pm 0.0018^{*}$ \\
\hline
\end{tabular}

Note. Values are expressed as the mean \pm SEM (for details, see Table 2 of Impagnatiello et al., 1998). Note that reelin is significantly decreased in all brain regions examined in the brains of schizophrenic patients.

$* P<0.05$.

** $P<0.01$.

*** $P<0.001$.

expression of $\mathrm{GAD}_{67}$, but not that of $\mathrm{GAD}_{65}$ protein, is drastically reduced. Subsequently, we obtained four diagnostic cohorts of postmortem brains from the Stanley Foundation (nonpsychiatric subjects, unipolar depressed, bipolar disorder with mania, and schizophrenia patients), each including 15 samples of Brodmann's area 9 (superior frontal gyrus) and cerebellum (Guidotti et al., 2000). Table 3 summarizes the various demographic variables of these four cohorts. For each brain sample, a quantitative analysis by RT-PCR was performed that included mutated internal standards (Grayson \& Ikonomovic, 1998) to quantify the following mRNAs: $G{ }_{67}$, $\mathrm{GAD}_{65}$, neuron-specific enolase (NSE), and reelin. Figure 4 shows that reelin and $\mathrm{GAD}_{67}$ mRNA expression is downregulated in the PFC of patients affected by schizophrenia or bipolar disorder with psychosis using as a reference point either the total RNA or the NSE mRNA expressed in each sample. In contrast, reelin and $\mathrm{GAD}_{67}$ mRNA levels are unchanged in unipolar depressed patients without psychosis. Similar results were obtained when the expression of the $400-\mathrm{kDa}$ reelin- and $\mathrm{GAD}_{67^{-}}$ like immunoreactive proteins were comparatively determined in the same tissue by western blot analysis. No changes were found in the content of DAB1 or $\mathrm{GAD}_{65}$ proteins. Statistical analyses of these data exclude the relevance of differences in PMI, age, gender, cause of death, drug abuse, brain $\mathrm{pH}$ or any other demographic variable reported in Table 3. Since the majority of psychotic patients received antipsychotic drug treatment, it was most important to establish that there was no correlation between the lifetime dosages of antipsychotic medication and the levels of $\mathrm{GAD}_{67}$ protein or reelin mRNA. Even psychotic patients that were never treated with antipsychotics showed reduced reelin and $\mathrm{GAD}_{67}$ mRNA expression (Guidotti et al., 2000). 
TABLE 3

Demographic Characteristics of the Four Cohorts of Postmortem Brains Obtained from the Stanley Foundation Neuropathology Consortium

\begin{tabular}{|c|c|c|c|c|}
\hline & \multirow[b]{2}{*}{$\begin{array}{l}\text { Nonpsychiatric } \\
\qquad(n=15)\end{array}$} & \multicolumn{3}{|c|}{ Patient cohort } \\
\hline & & $\begin{array}{l}\text { Unipolar depressed } \\
\qquad(n=15)\end{array}$ & $\begin{array}{l}\text { Schizophrenia } \\
\qquad(n=15)\end{array}$ & $\begin{array}{c}\text { Bipolar disorder } \\
(n=15)\end{array}$ \\
\hline Male/female & $9 / 6$ & $9 / 6$ & $9 / 6$ & $9 / 6$ \\
\hline Age (years) & $48 \pm 11$ & $46 \pm 9.3$ & $44 \pm 12$ & $42 \pm 13$ \\
\hline Postmortem interval (h) & $24 \pm 9.9$ & $27 \pm 4.7$ & $34 \pm 16$ & $32 \pm 15$ \\
\hline Brain $\mathrm{pH}$ & $6.3 \pm 0.061$ & $6.2 \pm 0.087$ & $6.2 \pm 0.087$ & $6.2 \pm 0.088$ \\
\hline Age of illness onset (years) & $\mathrm{N} / \mathrm{A}$ & $34 \pm 13$ & $23 \pm 8.3$ & $21 \pm 7.9$ \\
\hline Duration of illness (years) & $\mathrm{N} / \mathrm{A}$ & $13 \pm 11$ & $21 \pm 11$ & $23 \pm 10$ \\
\hline \multicolumn{5}{|l|}{ Cause of death } \\
\hline Suicide & None & 7 & 4 & 9 \\
\hline Cardiopulmonary & 13 & 7 & 8 & 4 \\
\hline Accident & 2 & 0 & 2 & 1 \\
\hline Other & 0 & 1 & 1 & 1 \\
\hline Family history of psychosis & 1 & 1 & 6 & 7 \\
\hline Severe sociofunctional deficit & None & None & 9 & 5 \\
\hline \multicolumn{5}{|l|}{ Antipsychotics } \\
\hline None & 15 & 15 & 3 & 5 \\
\hline Clozapine only & None & None & 2 & 2 \\
\hline Others $^{a}$ & None & None & 7 & 8 \\
\hline Clozapine/others & None & None & 3 & None \\
\hline Antidepressants & None & 9 & 5 & 7 \\
\hline Mood stabilizers & None & 3 & 5 & 10 \\
\hline \multicolumn{5}{|l|}{ Abuse/dependence } \\
\hline Alcohol & 0 & 3 & 2 & 2 \\
\hline Cocaine & 0 & 1 & 0 & 1 \\
\hline Polysubstance & 0 & 0 & 1 & 1 \\
\hline
\end{tabular}

${ }^{a}$ Haloperidol, chlorpromazine, risperidone, thioridazine.

\section{Downregulation of Reelin-Positive Cell Counts in PFC}

We also received from the Stanley Foundation coronal sections of PFC from each diagnostic cohort, which were immunostained for reelin protein and counterstained with Nissl or a neuronal nuclear-specific marker (NeuN) to recognize neurons; when Nissl stain was used, neurons were differentiated from glia using the criteria described by Benes (Benes et al., 1991). Some neurons that express reelin protein and are located in superficial layers of PFC appear to be small and ovoid. Extrapolating our findings in rodents and nonhuman primates (Pesold et al., 1998, 1999b; Rodriguez et al., 2000) to humans, these neurons are probably horizontal and bitufted GABAergic interneurons. In patients with schizophrenia or bipolar disorders with psychosis, the number of reelin-positive cells in the PFC is about 30\% lower than that found in unipolar depressed or nonpsychiatric subjects (Fig. 5). Since in the PFC of psychotic patients, the number of neurons is not changed as measured by counting either the number of Nissl-stained neurons in all patients (Fig. 5) or NeuN immunostained neurons in few sections (Guidotti et al., 2000), the decrease in the number of reelin-immunoreactive neurons observed in psychotic patients cannot be interpreted as due to a decrease in the number of GABAergic neurons. We hypothesized that due to a decreased expression of reelin protein in some interneurons, reelin cannot be detected because its expression level is below our detection capability (Guidotti et al., 2000). One concern is that the percentage decrease in the number of cells immunopositive for reelin in PFC (layers I and II) (Fig. 5) is smaller than the percentage of the decrease of the reelin protein estimated by Western blot in blocks of tissue (Impagnatiello et al., 1998). As mentioned earlier, most of the reelin protein is not located in cells but in the ECM. Hence, these cell counts do not include ECM reelin. However, ECM reelin homopolymerization and adhesion to dendritic shafts, spines, and synapses of pyramidal neurons are inherent in the mechanisms of reelin action (Anton et al., 1999; Dulabon et al., 2000). Because the amount of reelin protein located in the ECM and bound to dendrites is much greater 

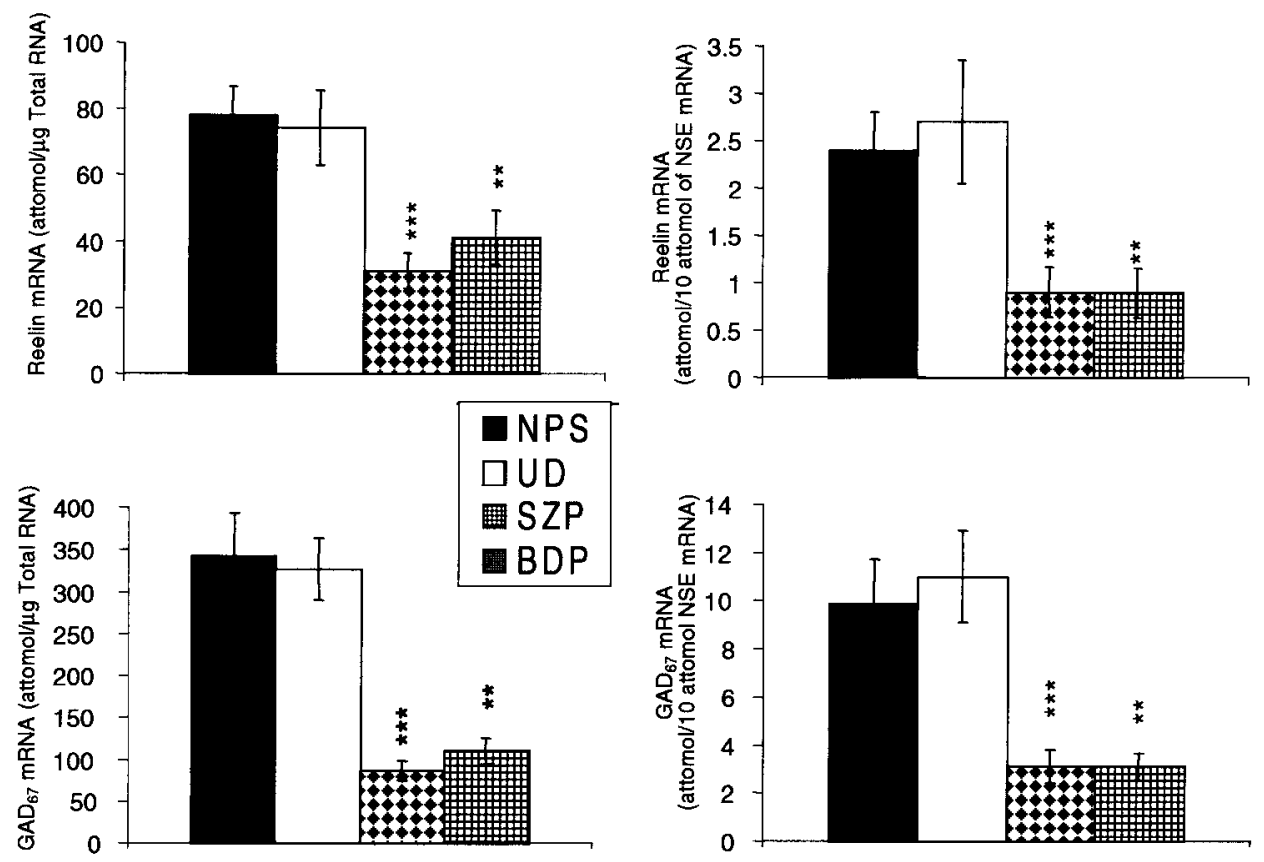

FIG. 4. Reelin and $\mathrm{GAD}_{67}$ mRNA content (mean \pm SEM) expressed for micrograms of total RNA (left), and for 10 attomol of NSE mRNA (right), in unipolar depressed (UD), schizophrenic (SZP), bipolar disorder with psychosis (BDP), and nonpsychiatric subjects (NPS). Note that patients with schizophrenia and bipolar disorder have significantly lower levels of reelin and $\mathrm{GAD}_{67}$ mRNA. $^{*} P<0.025,{ }^{* *} P<0.01, * * * P<$ 0.001. (For details, see Table 2 of Guidotti et al., 2000).

than that stored in neuronal somata at any given time, the decrease in reelin protein measured in blocks of tissue (Impagnatiello et al., 1998), which includes both cellular and ECM pools of reelin, must be greater than that measured by only counting the number of cells that have detectable levels of reelin (Pesold et al., 1999a, 1999b). The decreased number of reelin-positive neurons in the PFC of schizophrenia or bipolar

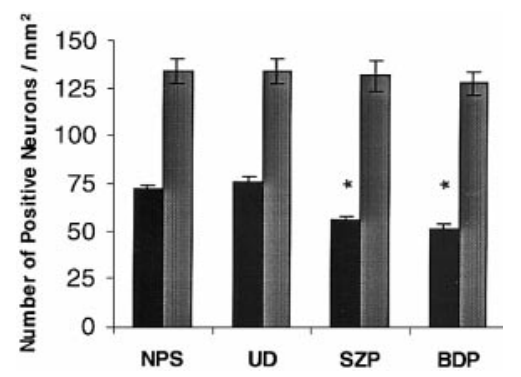

FIG. 5. Mean \pm SEM number of reelin-immunopositive neurons (dark bars) and number of Nissl-stained neurons (gray bars) in layer 1 of 20-micron sections taken through the superior gyrus (Brodmann's area 9) of patients with UD, SZP, BDP, and NPS. Note that the patients with SZP and BDP have significantly less reelin-positive neurons in PFC layer I, without any change in the total number of neurons present. ${ }^{*} P<0.001$. (For details, see Table 2 of Guidotti et al., 2000). disorder patients with psychosis was unrelated to postmortem interval, dose, duration, presence of antipsychotic medication (Fig. 6), or abuse of ethanol or addictive drugs (Guidotti et al., 2000).

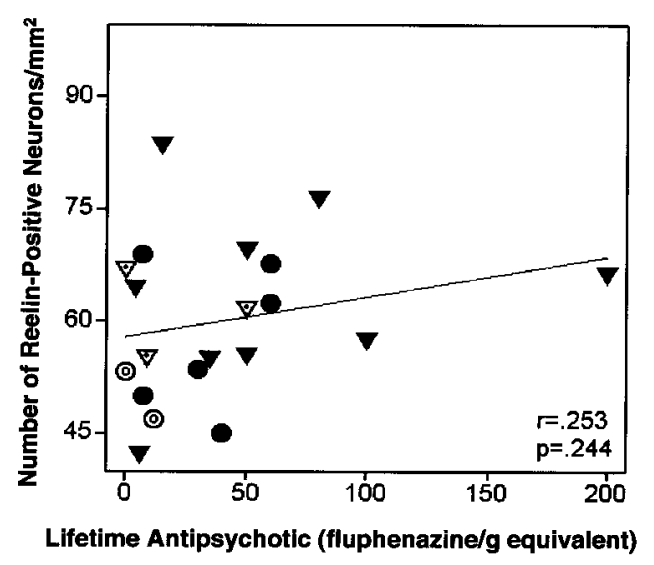

FIG. 6. Pearson's correlation between the number of reelin-positive cells and lifetime antipsychotic treatment normalized as fluphenazine/g equivalents for patients with schizophrenia (triangles), and bipolar disorder (circles). Open circles or triangles represent patients that received little or no antipsychotic medication. Note that the number of reelin-immunopositive neurons is not significantly related to antipsychotic treatment. 


\section{A Correlation between Reelin and $\mathrm{GAD}_{67}$ Expression Is Present in Cortex of Nonpsychiatric Subjects But Not in That of Schizophrenia or Bipolar Disorder Patients with Psychosis}

Before discussing the mechanism causing the downregulation of reelin and $\mathrm{GAD}_{67}$, it is important to keep in mind that the expression levels of these two proteins are positively correlated in the telencephalon of nonpsychiatric and unipolar depressed subjects (Guidotti et al., 2000). However, in patients with schizophrenia and bipolar disorder with psychosis, not only is the telencephalic expression of reelin and $\mathrm{GAD}_{67}$ protein reduced, but also these two parameters are no longer correlated (Guidotti et al., 2000). Based on the observation that the levels of $\mathrm{GAD}_{65}$ mRNA and protein, which presumably are expressed in all GABAergic neurons (Soghomonian \& Martin, 1998), are unchanged in the postmortem brains of psychotic patients (Guidotti et al., 2000), one can infer that the downregulation of $\mathrm{GAD}_{67}$ (Fig. 4) observed in schizophrenia and manic bipolar patients is not due to a primary neurodegenerative process of GABAergic neurons (Guidotti et al., 2000). Alternatively, one might suggest a specific link between the downregulation of reelin in the ECM and the reduction of $\mathrm{GAD}_{65}$ expression. We hypothesize that a decrease in dendritic spine density reported by others to occur in cortical neuropil of schizophrenia (Garey et al., 1998) and bipolar patients with mania (Rosoalija et al., 2000) may be secondary to the downregulation of reelin expression in the ECM. Thus, the correlation between reelin and $\mathrm{GAD}_{67}$ expression may indicate that the physiological expression level of dendritic spine influences the number of GABAergic, glutamatergic, and monoaminergic nerve terminals that are expressed. In fact, the absence of synaptic targets reduces the branching of afferent axon terminals. In addition, this conclusion suggests that $\mathrm{GAD}_{65}$ does not compensate for the $\mathrm{GAD}_{67}$ deficit, inviting speculation that although the two enzymes regulate the synthesis of GABA, they may have specific and unrelated localization and perhaps functions. $\mathrm{GAD}_{67}$ may be located throughout the neuron including somata, whereas $\mathrm{GAD}_{65}$ is preferentially located in axons or dendrites of GABAergic cells, according to Soghomonian and Martin (1998). It remains an open question whether GABA content is downregulated and consequently that GABAergic function is compromised when $\mathrm{GAD}_{67}$ is decreased. In support of this possibility is the finding that the binding of the GABA agonist muscimol is increased (Benes et al., 1992) in some brain areas of schizophrenia patients when $\mathrm{GAD}_{67}$ is downregu-

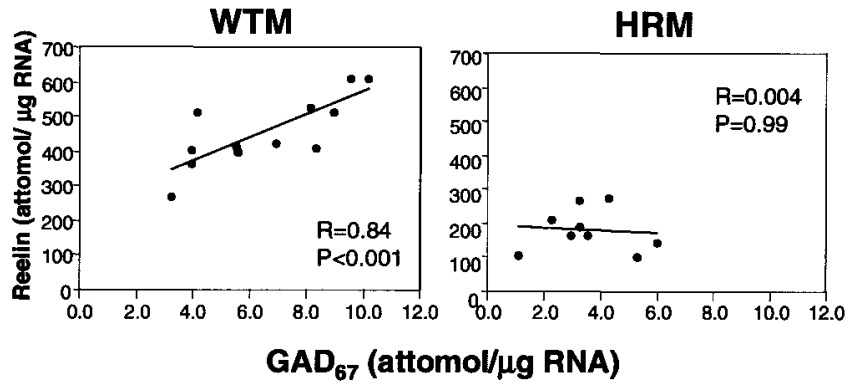

FIG. 7. Pearson's correlation between reelin and $\mathrm{GAD}_{67}$ mRNA in the frontal cortex of wild-type (WTM) and heterozygote reeler mice (HRM). Note that the significant positive correlation between reelin and $\mathrm{GAD}_{67}$ is disrupted in the HRM. In addition, note that the levels of both reelin and $\mathrm{GAD}_{67}$ are lower in the reeler heterozygote mice (data from Carboni et al., 2000).

lated, while the expression of certain $\mathrm{GABA}_{\mathrm{A}}$ receptor subunits may be increased or decreased (Benes et al., 1992; Impagnatiello et al., 1998). Both findings are indicative of a plastic adaptation of $\mathrm{GABA}_{\mathrm{A}}$ receptor expression compensatory to a change in GABAergic tone.

The presence of a correlation between reelin and $\mathrm{GAD}_{67}$ levels in the PFC of nonpsychiatric subjects and unipolar depressed patients (Guidotti et al., 2000), which do not exhibit a downregulation of these two parameters, reinforces the hypothesis that this correlation reflects a functional interaction. When spine expression and its GABAergic innervation are downregulated as in schizophrenia (Garey et al., 1998; Glantz \& Lewis, 2000; Rosoklija et al., 2000), bipolar disorder with psychosis (Rosoklija et al., 2000), and in reelin-haploinsufficient heterozygote mouse (Tueting et al., 1999; Liu et al., 2001), this correlation vanishes (Guidotti et al., 2000; Liu et al., 2001; and Fig. 7). According to our interpretation, this lack of correlation indirectly suggests that reelin plays a role in dendrite trophism and dendritic spine expression regulation.

\section{REELIN DEFICIT IN HAPLOINSUFFICIENT HETEROZYGOUS REELER MOUSE}

To investigate the possible mechanisms operative in maintaining the equilibrium between reelin and $\mathrm{GAD}_{67}$, and at the same time to shed some light on the possible consequences of reelin expression downregulation, the possibility emerges that reelin functions in dendritic spine plasticity. Hence, 
TABLE 4

Reelin, $\mathrm{GAD}_{67}$, and $\mathrm{GAD}_{65}$ mRNA (attomol/ $\mu \mathrm{g}$ RNA) in the Brains of Wild-Type (WTM), Heterozygote Reeler Mice (HRM), and Heterozygote $\mathrm{GAD}_{67}$ Knockout Mice (HGM)

\begin{tabular}{lccc}
\hline & \multicolumn{3}{c}{ Frontal cortex } \\
\cline { 2 - 4 } mRNA & WTM & HRM & HGM \\
\hline Reelin & $190 \pm 9$ & $99 \pm 16^{*}$ & $145 \pm 24$ \\
GAD $_{67}$ & $7.0 \pm 0.8$ & $4.2 \pm 0.59^{*}$ & $3.2 \pm 0.38^{*}$ \\
GAD $_{65}$ & $48 \pm 14$ & $40 \pm 12$ & $42 \pm 11$ \\
\hline
\end{tabular}

Note. Each value is the mean \pm SEM of 4 to 6 mice. Student's $t$ test, two-tailed ${ }^{*} P<0.01$-statistical comparison between WTM and HRM or HGM (for details, see Table 1 of Liu et al., 2001).

its decrease may be associated with neuropil hypoplasticity, which in turn may cause a sharp decline in presynaptic GABAergic nerve terminal expression as found in the brain of patients with schizophrenia and bipolar disorders with psychosis (Weinberger et al., 1982; Selemon \& Goldman-Rakic, 1999; Garey et al., 1998; Glantz \& Lewis, 2000; Rosoklija et al., 2000).

\section{The Heterozygous Reeler Mouse (HRM) as a Genetic Model of Reelin Downregulation}

The frontal cortex in the HRM model expresses only $50 \%$ of the normal amount of reelin mRNA and protein present in the wild-type mouse (see Fig. 7; Table 4; and Tueting et al., 1999) but fails to show the anatomical or behavioral symptoms that phenotypically characterize its reeler null mutant littermate. This reelin downregulation is associated with a reduction of $\mathrm{GAD}_{67}$ mRNA and protein expression, while $\mathrm{GAD}_{65}$, which is believed to coexist with $\mathrm{GAD}_{67}$ in the same neuron, remains unchanged (see Tables 1 and 4). The HRM phenotype exhibits the following signs (see Table 1 for a comparison with the brain microanatomy of schizophrenia): (1) a decrease in the expression of reelin in horizontal, bitufted, and Martinotti GABAergic neurons of the neocortex (Liu et al., 2001), (2) a selective decrease of cortical neuropil expression associated with an apparent increase in neuronal packing density (Liu et al., 2001), (3) an altered distribution of nicotinamide adenine dinucleotide phosphate-positive GABAergic neurons reminiscent of that observed in schizophrenia brains (Tueting et al., 1999), and (4) a decreased expression of dendritic spines on pyramidal neurons of the frontal cortex and hippocampus (Fig. 8) (Costa et al., 2000; Liu et al., 2001).

Moreover, the HRM exhibits the following biochemical alterations: (1) a postpubertal appearance of a downregulation in sensory motor gating reminiscent of that expressed by almost every schizophrenia patient and some healthy members of schizophrenia families (Tueting et al., 1999), (2) a decreased acquisition rate in the radial maze task when compared with wild-type mice (Carboni et al., 2000), (3) when HRM are socially isolated, their aggression to an intruder mouse is limited and atypical, quickly showing indifference (unpublished result). One might infer that this indifference is an index of social withdrawal. We are currently studying in more detail the social behavior of the HRM model. However, we can safely state that the haploinsufficient reeler mouse recapitulates several neuroanatomical and neurochemical abnormalities found in the cortex of schizophrenia and bipolar disorder patients with psychosis.

\section{In HRM, Reelin Downregulation Precedes the GAD $_{67}$ Expression Deficit}

An important question to be addressed with the HRM model is whether a primary defect of the $\mathrm{GAD}_{67}$ gene expression is responsible for the downregulation of reelin expression and dendritic spine density, or vice versa. These studies may allow us to exclude that the reelin deficit precedes a progressive downregulation of dendritic spines and the consequent reduction of branching in innervating GABAergic axons. So far, we have addressed this question by comparing the HRM with the heterozygote $\mathrm{GAD}_{67}$ knockout mouse (HGM). As shown in Table 4, as expected, the HGM expresses a downregulation of $\mathrm{GAD}_{67}$ but has a normal level of dendritic spines and normal levels of reelin mRNA and protein (Liu et al., 2001). Thus, it appears that by some mechanism still to be clarified (trophic action of reelin on dendritic spines?), a selective reelin downregulation lowers dendritic spine density and consequently $\mathrm{GAD}_{67}$ expression in innervating GABAergic terminal axons, while a primary downregulation of $\mathrm{GAD}_{67}$ fails to influence reelin and dendritic spine expression (Liu et al., 2001).

\section{ECM Reelin Expression in HRM}

In electron microscopy studies of HRM, we have observed that this mouse model exhibits a low level of ECM reelin (Liu et al., 2001). In contrast, it appears that in the HGM model, GABAergic neurons and ECM express normal amounts of reelin (Table 4). Since we have found that in-vitro neuronal secretion of reelin depends on its synthesis rate (Lacor et al., 2000), we suggest that the amount of reelin deposition in the ECM relates to its synthesis rate, which is decreased in 

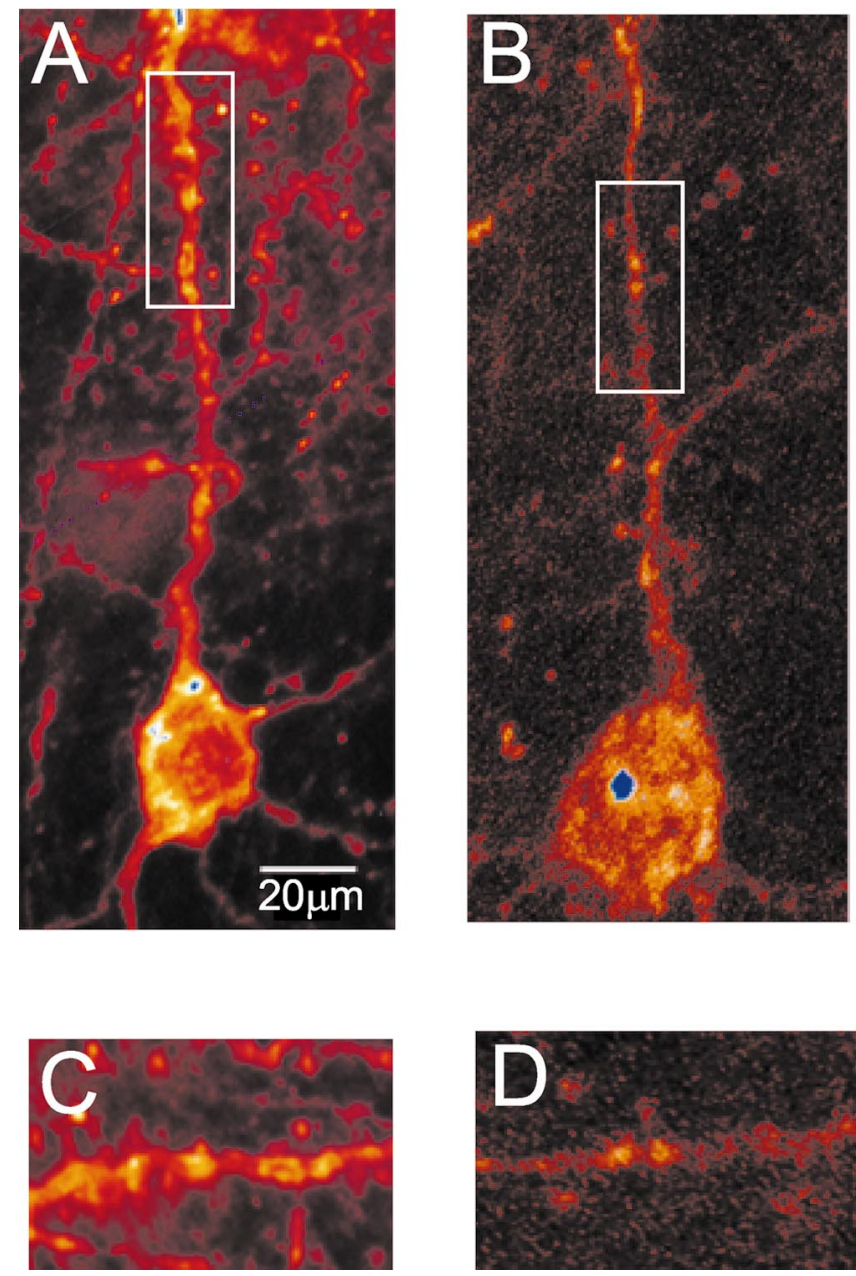

FIG. 8. Photomicrographs showing Golgi-impregnated or $\Delta^{9}$-Dilstained dendritic spines of Layer III frontal motor cortex pyramidal neurons in wild-type mice (WTM) or heterozygous reeler mice (HRM). (A and B) High magnification of basilar (B2) dendritic branches stained with Golgi method (for details, see Liu et al., 2001). (C and D) High magnification of apical dendrites stained with $\Delta^{9}$-Dil, according to Hosokawa et al. (1992) (for further details see Liu et al., 2001).

HRM but not in HGM (Liu et al., 2001). Hence, we infer that in the haploinsufficient HRM model, the rate of reelin synthesis is inappropriate to maintain a physiological steady-state level of reelin expression in the ECM.

The HRM fails to manifest the neuroanatomical and behavioral phenotypic traits of null mutant reelin mice. The neuronal positioning and layering in the telencephalon and cerebellum of HRM appears normal. However, the increased neuronal packing density and a decrease of cortical thickness, perhaps secondary to neuropil hypoplasticity, as well as the decrease of dendritic spine expression density of motor frontal cortex pyramidal neurons in these animals suggest that reelin haploinsufficiency may be a factor in the dynamic of cortical neuropil expression and plasticity (Liu et al., 2001).

The hypothesis that reelin decorating and adhering to basal and apical dendritic shafts and spines of pyramidal neurons (Rodriguez et al., 2000) has a trophic role in the neuropil is in line with the view expressed by Zec \& Tieman (1994) that dendrite development not only reflects the expression of a programmed intrinsic mechanism, but it is also due to a dendritic plasticity related to ECM proteins (including reelin) operative in promoting dendritic arbor development (Xiao et al., 1991; Humphries, 1996; Staubli et al., 1998; Pinkstaff et al., 1999).

\section{Plasticity in Dendritic Spines of HRM}

Studies of synaptic plasticity have contributed to the present belief that synaptic activity may regulate the local synthesis of cytoskeletal proteins in dendrites to maintain the steady-state expression of dendritic spines (Garnes et al., 1988; Toni et al., 1999, Matus \& Shepherd, 2000; Wells et al., 2000). We may also suggest that dendritic resident mRNAs play a major role in this process (Klintsova \& Greenough, 1999; Eberwine, 1999; Kuhl \& Skehel, 1998).

The role of the dendritic spine downregulation in mental deficiency was first suggested by Purpura (1975). The interesting capacity of spines to synthesize proteins locally from dendritic resident mRNAs documented by Crino and Eberwine (1996) not only suggests that the spine protein composition, shape, and volume can change as a function of this synthesis, but also involves the possibility that dendritic spines via the synthesis of new proteins (Eberwine, 1999) can send specific messages to the nucleus (a process referred to as nuclear imprinting) and thereby adapt nuclear DNA transcription to the needs of specific dendritic resident mRNA expression (Crino et al., 1998; Miyashiro et al., 1994). If reelin and DAB1 are involved in the regulation of protein synthesis in spines, then one can postulate a functional nuclear imprinting regulated by reelin and perhaps by other ECM proteins bringing extrasynaptic information to act on integrin receptors expressed in dendritic spines (Figs. 2 and 3). Klintsova and Greenough (1999) have shown that the activation of metabotropic glutamate receptors located in spines can stimulate local protein synthesis (Weiler et al., 1993, 1994, 1997) via the activation of a mRNA encoding for FMRP, a member of the FMR1 protein family (Ashley et al., 1993; Siomi et al., 1993). FMRP is absent in the filopodia and abnor- 
mal spines of patients with fragile X-chromosome mental deficiency (Cormeyer et al., 1997) but is present in dendritic spines of normal individuals. FMRP is a binding protein to mRNAs associated with polyribosomes that changes the translation efficiency of mRNAs resident in dendritic spines (Klintsova \& Greenough, 1999). Thus, our working hypothesis is that protein synthesis in spines can be regulated via the signal transduction pathway activated by glutamate or other neurotransmitters acting on spine located metabotropic or ionotropic receptors and by reelin acting on integrin receptors expressed on dendrites enriched in specific subtypes of resident mRNAs.

Since in the neocortex, dendritic spines are innervated by GABAergic and glutamatergic terminals as well as by dopaminergic, serotonergic, or cholinergic axonal arborizations (DeFilipe \& Farinas, 1992; Somogyi et al., 1998; Goldman-Rakic et al., 1990; Smiley et al., 1992), we wonder whether the modulation of nuclear imprinting mediated by the reelin binding on dendrites and spine postsynaptic densities (Rodriguez et al., 2000) is a mechanism to be considered to explain the beneficial effect of dopamine receptor antagonists in psychosis. In this regard, the specific question that must be addressed is whether long-term treatment with antipsychotics modulates spine protein synthesis and thereby overcome the deficient spine expression density detected in basal and apical dendrites of pyramidal neurons in PFC and hippocampus of schizophrenia and bipolar disorder patients (Garey et al., 1998; Glantz et al., 2000; Rosoklija et al., 2000). A germane question is: can ECM protein-mediated imprinting of neuronal nuclei be considered an additional extrasynaptic functional aspect of the action of antipsychotic-induced amelioration of schizophrenic symptoms?

\section{REELIN, GAD ${ }_{67}$, DENDRITIC SPINE DENSITY, AND QUALITY OF PSYCHOTIC SYMPTOMS}

In considering the remarkable complexity of the syndromes associated with schizophrenia and bipolar disorder with mania, we have focused our attention on the possibility that the downregulation of a pleiotropic gene such as reelin may influence not only the vulnerability to these two disorders, by changing neuronal migration and final positioning during embryonic corticogenesis, but it may also continue to exert its influence in the operation of adult telencephalic synaptic spine plasticity by participating in the mod- ulation of complex genomic interactions occurring in the dendritic spines, their synapses and shafts in various areas of cortex and hippocampus. Since the vast majority of excitatory and inhibitory synapses in the cortex are expressed on dendritic spines of pyramidal neurons (Gray, 1959; DeFilipe \& Farinas, 1992; Goldman-Rakic \& Selemon, 1997; Fischer et al., 2000), where virtually all of the glutamatergic afferent neurons and more than $80 \%$ of intrinsic GABAergic axons converge, one may attribute the characteristic variability of psychotic symptoms expressed by schizophrenia and bipolar disorder patients as due to an alteration of the dynamic processes that maintain the required dendritic spine density and their appropriate presynaptic GABAergic, glutamatergic, and monoaminergic innervation in some but not in other neocortical areas. Such a possibility can be verified by answering the following questions: (1) Does a long-term administration of antipsychotics modify spine dystrophy of HRM only in the selected population of spines that include dopamine, and depending on the antipsychotic, also in spines expressing specific serotonin or acetylcholine receptors? and (2) Can drugs acting as agonists of integrin receptor subtypes expressed in dendritic spines be associated with currently-used antipsychotics to improve the overall expression of dendritic spines in the HRM model? These questions are directed to test whether there is a preferential location of ECM reelin in dendrites and spines expressing GABAergic synapses, and to the possibility that spine dystrophy is secondary to a defective GABAergic modulation of the triadic spine afferents [i.e., glutamate, monoamines, and GABA (Nusser, 1999)] (Fig. 2). Probably an excessive or a defective $\mathrm{Ca}^{2+}$ influx in a spine with a downregulation of GABAergic modulation brings about spine dystrophy (Fischer et al., 2000; Yuste et al., 2000). Alternatively, if we detect that reelin does not selectivity localize in GABAergic spine synapses, then we have to accept the working hypothesis that reelin has an indiscriminate trophic influence on synapses and on dendritic spines and we must investigate a reelin-induced cascade of events mediated through integrin or cadherin receptors. One inclusive approach will be to study how the autophosphorylation of integrin-associated tyrosine kinases can be modified in PFC slices of rats receiving antipsychotics selected from those currently prescribed to schizophrenia and bipolar disorder patients with psychosis.

In this study one might test the working hypothesis that the onset of bipolar disorder or schizophrenia symptoms in adolescence and early adulthood is attributable to functional deficits related to reelin 
downregulation occurring in the neuropil during late development pruning (axonal and dendritic) (Mirnics et al., 2000). Until adolescence, the deficit may be compensated by a redundancy in neuronal circuits. When this redundancy is drastically reduced by dendritic pruning occurring in early adulthood (Segal et al., 2000), such a process may facilitate the explosion of schizophrenia or bipolar disorder symptoms. The altered dendritic spine dynamics compounded by the completion of dendritic pruning in early adulthood may result in a decreased brain volume reported to occur in schizophrenia brain by Johnstone et al. (1976) and now documented by imaging studies (Altshuler et al., 2000; Crespo-Facorro et al., 2000; Falkai et al., 2000).

\section{A GENETIC PERSPECTIVE OF THE NEURODEVELOPMENTAL HYPOTHESIS OF SCHIZOPHRENIA ETIOLOGY}

The comparisons of adoptees from schizophrenia families strongly indicate that a genetic defect may be operative in the etiology of schizophrenia, bipolar disorder with mania, and probably other diseases affecting cognition (Kety et al., 1994). Considering the lack of Mendelian transmission and the insufficient concordance of schizophrenia found in monozygotic twins, it is often suggested that in the genetic background of schizophrenia there may be a multigenic disorder. Since schizophrenia and bipolar disorders share the expression of a number of psychophysically detectable objective symptoms that are also present in the healthy relatives of these patients, it is generally believed that a multigenic origin may well be the most logical explanation. We propose that such an explanation may not be the only alternative available. Another alternative to be considered is, for example, a pleiotropic gene downregulation that operates during brain development but which also continues to function after brain maturation in neocortex, hippocampus, and cerebellum causing a dysfunction in the dynamic steady state of dendritic spine expression (Halpain, 2000) in selected cortical areas and leading to a variable degree of neuropil hypoplasia depending on the degree of disruption of dynamic processes that maintain dendritic spine expression at a given steady state (Harris, 1997). We intend to pursue such a working hypothesis considering that the downregulation of reelin (a pleiotropic gene product), which we have detected in postmortem brain of schizophrenia and bipolar disorder patients with psychosis is responsible at least in part for neuropil hypoplasia. We will pro- ceed to test this hypothesis using the dendritic spine downregulation in the genetic HRM model (Liu et al., 2001). Pending this confirmation, we plan further studies in nonhuman primates in which we envision inducing reelin downregulation by injecting a recombinant adenovirus expressing reelin antisense transcripts. We have already prepared and successfully tested these transcripts in cultures of cerebellar granule neurons from normal rats (Lacor et al., 2000).

\section{CONCLUDING CONSIDERATIONS}

In closing, we would like to comment on the analogies of reelin downregulation expressed in schizophrenia and bipolar disorder patients with psychosis.

Traditionally these two disorders are considered two separate entities. The bipolar disorder usually manifests itself as a disturbance of mood, whereas schizophrenia is primarily conceived as a disorder of cognition. Mood stabilizers are effective in bipolar illness and not in schizophrenia. Despite these differences, similarities in the epidemiology of family studies suggest that these two groups of disorders are more closely related than previously believed. They have somewhat similar age of onset, worldwide distribution, risk for suicide, equal risk for male and female, and somewhat well established commonalties in genetic susceptibility. Because bipolar disorder with mania and schizophrenia nosologic classes each includes multiple syndromes disease entities (with some clinical analogies), our studies encourage the view that some of these disease entities might produce syndromes that can be assigned to either nosologic group depending on the genetic background from which they arise. Among the several etiological factors considered in each illness there might be common etiological elements shared by both disorders.

Our studies imply that vulnerability to psychosis may have a common anatomical background; namely, a decrease in the expression of dendritic spines and this, based on studies in HRM model (Liu et al., 2001), can be related to a downregulation of reelin gene expression causing a reduction of $\mathrm{GAD}_{67}$ and neuropil expression. However due to the phenotypic complexity of schizophrenia and bipolar disorders with psychosis, the concept that reelin may be a common vulnerability factor in these psychiatric disorders remains a possible hypothesis to be tested in the future with pharmacological agents acting at the reelin receptors (integrins?) or at various steps of the reelin signal transduction pathway. We are currently studying the genetic background of reelin downregulation by char- 
acterizing the role of methylation in the regulation of the reelin promoter region in families of schizophrenia patients (Grayson et al., 2000). Also, we are investigating a CGG trinucleotide repeat within the 5 ' untranslated portion of the reelin mRNA. Studying the repeat length in 100 trios of schizophrenia families (For the demographic information of these families see Egan et al., 2001) we have obtained evidence that there is a concordance between the repeat length and schizophrenia symptomatology. Should these preliminary data be consolidated one can propose that the repeat length may explain the down regulation of reelin because the methylation of the promoter may depend on the length of the repeat. We know that changes in promoter methylation change the expression of reelin in a cell-dependent manner.

\section{ACKNOWLEDGMENT}

This work was supported by NIH grants MH062188 (to A.G.) and MH062090 (to E.C.).

\section{REFERENCES}

Akbarian, S., Kim, J. J., Potkin, S. G., Hagman, J. O., Tafazzoli, A., Bunney, Jr., W. E., \& Jones, E. G. (1995) Gene expression for glutamic acid decarboxylase is reduced without loss of neurons in prefrontal cortex of schizophrenics. Arch. Gen. Psychiatr. 552, 258266.

Akbarian, S., Kim, J. J., Potkin, S. G., Hetrick, W. P., Bunney Jr., W. E., \& Jones, E. G. (1996) Maldistribution of interstitial neurons in prefrontal white matter of schizophrenics. Arch. Gen. Psychiatr. 53, 425-436.

Alcantara, S., Ruiz, M., D'Arcangelo, G., Ezan, F., de Lecea, L., Curran, T., Sotelo, C., \& Soriano, E. (1998) Regional and cellular patterns of reelin mRNA expression in the forebrain of the developing and adult mouse. J. Neurosci. 18, 7779-7799.

Altshuler, L. L., Bartzokis, G., Grieder, T., Curran, J., Jimenez, T., Leight, K., Wilkins, J., Gerner, R., \& Mintz, J. (2000) An MRI study of temporal lobe structures in men with bipolar disorder or schizophrenia. Biol. Psych. 48, 147-162.

Andreasen, N. L., Nasrallah, H. A., Dunn, V. D., Olson, S. C., Grove, W. M., Ehrhardt, J. L., Coffman, J. A., \& Crossett, J. H. W. (1986) Structural abnormalities in the frontal system in schizophrenia: A magnetic resonance imaging study. Arch. Gen. Psychiatr. 43, 136144.

Anton, E. S., Kreidberg, J. A., \& Rakic, P. (1999) Distinct functions of $\alpha 3$ and $\alpha(\mathrm{V})$ integrin receptors in neuronal migration and laminar organization of the cerebral cortex. Neuron 22, 277-289.

Ashley, C. T. Jr., Wilkinson, K. D., Reines, D., \& Warren, S. T. (1993) FMR1 protein: Conserved RNP family domains and selective RNA binding. Science 262, 563-566.

Benes, F. M. (2000) Emerging principles of altered neuronal circuitry in schizophrenia. Brain Res. Rev. 31, 251-269.

Benes, F. M., McSparren, J., Bird, E. D., Sangiovanni, J. P., \& Vincent,
S. L. (1991) Deficits in small interneurons in prefrontal and cingulate cortices of schizophrenic and schizoaffective patients. Arch. Gen. Psychiatr. 48, 996-1001.

Benes, F. M., Vincent, S. L., Alsterberg, G., Bird, E. D., \& San Giovanni, J. P. (1992) Increased GABA receptor binding in superficial layers of schizophrenia cingulate cortex in schizophrenia. J. Neurosci. 12, 924-929.

Bertolino, A., Callicott, J. H., Nawroz, S., Mattay, V. S., Duyn, J. H., Tecleschi, G., Frank, J. A., \& Weinberger, D. R. (1998) Reproducibility of proton magnetic resonance spectroscopic imaging in patients with schizophrenia. Neuropsychopharmacal. 18, 1-9.

Bloom, F. E. (1993) Advancing a neurodevelopmental origin for schizophrenia. Arch. Gen. Psychiatr. 50, 224-227.

Bunney, Jr., W. E., \& Bunney, B. G. (2000) Evidence for a compromised dorsolateral prefrontal cortical parallel circuit in schizophrenia. Brain. Res. Rev. 31, 138-146.

Carboni, G., Dong, E., Pesold, C., Tueting P., Li, X., Costa, E., \& Guidotti, A. (2000) Heterozygous reeler mice $(\mathrm{rl}+/-)$ display increased cognitive impairment when treated with dizolcipine. Soc. Neurosci. Abs. 26(1), 396.12, p. 1058.

Comery, T. A., Harris, J. B., Willems, P. J., Oostra, B. A., Irwin, S. A., \& Weiler, I. J. (1997) Abnormal dendritic spine in fragile X knockout mice: Maturation and pruning deficit. Proc. Natl. Acad. Sci. USA 94, 5401-5404.

Costa, E., Liu, W.-S., Pesold, C., Rodriguez, M. A, \& Guidotti, A. (2000) Downregulation of dendritic spine expression in prefrontal cortex pyramidal neurons of heterozygous reeler mouse. Soc. Neurosci. Abstr. 26(2), 580.18, P. 1561.

Crespo-Facorro, B., Kim, J. J. Andreasen, N. C., O'Leary, D. S., \& Magnotta, V. (2000) Regional frontal abnormalities in schizophrenia: A quantitative gray matter volume and cortical surface size study. Biol. Psych. 48, 110-119.

Crino, P., \& Eberwine, J. (1996) Molecular characterization of the dendritic growth cone: regulated mRNA transport and local protein synthesis. Neuron 17, 1173-1187.

Crino, P., Khodakhah, K., Becker, K., Ginsberg, S., Hemby, S., \& Eberwine, J. (1998) Presence and phosphorylation of transcription factors in dendrites. Proc. Natl. Acad. Sci. USA 95, 2313-2318.

D'Arcangelo, G., Homayouni, R., Keshvara, L., Rice, D. S., Sheldon, M., \& Curran, T. (1999) Reelin is a ligand for lipoprotein receptors. Neuron 24, 471-479.

D'Arcangelo, G., Miao, G. G., Chen, S. C., Soares, H. D., Morgan, J. I., \& Curran, T. (1995) A protein related to extracellular matrix proteins is deleted in the mouse mutant reeler. Nature 374, 719723.

DeFilipe, J., \& Farinas, I. (1992) The pyramidal neuron of the cerebral cortex: Morphological and chemical characteristics of the synaptic inputs. Progr. Neurobiol. 39, 563-607.

Dulabon, L., Olson, E. C., Taglienti, M. G., Eisenhuth, S., McGrath, B., Walsh, C. A., Kreidberg, J. A., \& Anton, E. S. (2000) Reelin binds $\alpha 3 / \beta 1$ integrin and inhibits neuronal migration. Neuron 27, 33-44.

Eberwine, J. H. (1999) Dendritic localization of mRNAs and local protein synthesis. In Dendrites (G. Stuart, N. Spruston, and M. Häusser, Eds.), pp. 35-67. Oxford Univ. Press, New York.

Egan, M. F., Goldberg, T. E., Kolachana, B. S., Callicott, J. H., Mazzanti, C. M., Straub, R. E., Goldman, D., \& Weinberger, D. R. (2001) Effect of COMT Val ${ }^{108 / 158}$ Met genotype on frontal lobe function and risk for schizophrenia. Proc. Natl. Acad. Sci. USA 98, 6917-6922

Falkai, P., Schneider-Axmann, T., \& Honer, W. G. (2000) Entorhinal cortex pre-alpha cell clusters in schizophrenia: quantitative evidence of a developmental abnormality. Biol. Psych. 47, 937-943. 
Fatemi, S. H., Earle, J. A., \& McMenomy, T. (2000) Reduction in Reelin immunoreactivity in hippocampus of subjects with schizophrenia, bipolar disorder and major depression. Mol. Psychiatr. 5, 654-663.

Fiala, J. C, \& Harris, R. M. (1999) Dendritic structure. In Dendrites (G. Stuart, N. Spruston, and M. Häusser, Eds.), pp. 1-34. Oxford Univ. Press, New York.

Fischer, M., Kaech, S., Wagner, U, Brinkhaus, H., \& Matus, A. (2000) Glutamate receptors regulate actin-based plasticity in dendritic spines. Nature Neurosci. 3, 887-894.

Garey, L. J., Ong, W. Y., Patel, T. S., Kanani, M., Davis, A., Mortimer, A. M., Barnes, T. R., \& Hirsch, S. R. (1998) Reduced dendritic spine density on cerebral cortical pyramidal neurons in schizophrenia. J. Neurol. Neurosurg. Psychiatry 65, 446-453.

Garner, C. C., Tucker, R. P., \& Matus, A. (1988) Selective localization of messenger RNA for cytoskeletal protein MAP2 in dendrites. Nature 336, 674-677.

Giancotti, F. G., \& Ruoslahti, E. (1999) Integrin signaling. Science 285(5430), 1028-1032.

Gilmore, E. C., Ohshima, T., Goffinet, A. M., Kulkarni, A. B., \& Herrup, K. (1998) Cyclin-dependent kinase 5-deficient mice demonstrate novel developmental arrest in cerebral cortex. J. Neurosci. 18, 6370-6377.

Glantz, L. A., \& Lewis, D. A. (2000) Decreased dendritic spine density on prefrontal cortical pyramidal neurons in schizophrenia. Arch. Gen. Psychiatr. 57, 65-73.

Gleeson, J. G., \& Walsh, C. A. (2000) Neuronal migration disorders: from genetic diseases to developmental mechanisms. Trends Neurosci. 23, 352-359.

Goldman-Rakic, P. S., Lidow, M. S., \& Gallagher, D. W. (1990) Overlap in dopaminergic, adrenergic and serotonergic receptors and complementarily of their subtypes in primate prefrontal cortex. J. Neurosci. 10, 2125-2138.

Goldman-Rakic, P. S., \& Selemon, L. D. (1997) Functional and anatomical aspects of prefrontal pathology in schizophrenia. Schizophr. Bull. 23, 437-458.

Gray, E. G. (1959) Electron microscopy of synaptic contacts on dendritic spines of cerebral cortex. Nature 183, 1592-1594.

Grayson, D. R., \& Ikonomovic, S. (1998) Competitive RT-PCR quantitate steady-state mRNA levels. In Neuro Methods, Vol. 34. In Vitro Neurochemical Techniques (A. A. Boulton, G. B. Baker, and A. N. Bateson, Eds.), pp. 127-151. Humana Press, New York.

Grayson, D. R., Uzunov, D. P., Chen, Y., Siyanova, E., Raca, G., Sharma, R. P., Mirkin, S., \& Costa, E. (2000) Studies of molecular mechanisms regulating reelin gene expression. Biol. Psych. 47, 41S.

Guidotti, A., Auta, J., Davis, J. M., DiGiorgi-Gerenini, V., Dwivedi, J., Grayson, D. R., Impagnatiello, F., Pandey, G. N., Pesold, C., Sharma, R. F., Uzunov, D. P., \& Costa, E. (2000) Decreased reelin and glutamic acid decarboxylase 67 (GAD67) expression in schizophrenia and bipolar disorders. Arch. Gen. Psychiatry 57, 1061-1069.

Halpain, S. (2000) Actin and the agile spine: how and why do dendritic spines dance? Trends Neurosci. 23, 141-146.

Harris, K. M. (1999) Structure, development, and plasticity of dendritic spines. Curr. Opin. Neurobiol. 9, 343-348.

Haydar, T. F., Wang, F., Schwartz, M. L., \& Rakic, P. (2000) Differential modulation of proliferation in the neocortical ventricular and subventricular zones. J. Neurosci. 20, 5764-5774.

His, W. (1891) Die Entwiklung Des Menschlicher Rautenhirns Von Ende Des Ersten Bis Zum Beginn Des Dritten Monats. Verlangwertes Mark ABH Kon Sachs Ges Wiss Math. Phys. Ki 17-1-74.

Hong, S. E., Shugart, Y. Y., Huang, D. T., Shahwan, S. A., Grant,
P. E., Hourihane, J. O., Martin, N. D. T., \& Walsch, C. A. (2000) Autonomic recessive lissencephaly with cerebellar hypoplasia is associated with human rein mutations. Nat. Genet. 26, 93-96.

Hosokawa, T., Bliss, T. V., Fine, A., (1992) Persistence of individual dendritic spines in living brain slices. Neuroreport 3, 477-480.

Howell, B. W., Hawkes, R., Soriano, P., \& Cooper, J. A. (1997) Neuronal positioning in the developing brain is regulated by mouse disabled-1. Nature 389, 733-737.

Hourihane, J. O., Bennett, C. P., Chaudhuri, R., Robb, S. A., \& Martin, N. D. T. (1993) A sibship with a neuronal migration defect, cerebellar hypoplasia and congenital lymphoedema. Neuropediatrics $24,43-46$.

Humphries, M. J. (1996) Integrin activation: The link between ligand binding and signal transduction. Curr. Opin. Cell Biol. 8, 632-640.

Impagnatiello, F., Guidotti, A. R., Pesold, C., Dwivedi, Y., Caruncho, H., Pisu, M. G., Uzunov, D. P., Smalheiser, N. R., Davis, J. M., Pandey, G. N., Pappas, G. D., Tueting, P., Sharma, R. P., \& Costa, E. (1998) A decrease of reelin expression as a putative vulnerability factor in schizophrenia. Proc. Natl. Acad. Sci. USA 95, 1571815723.

Johnstone, E. C., Crow, T. J., Frith, C. D., Husband, J., \& Kreel, L. (1976) Cerebral ventricular size and cognitive impairment in chronic schizophrenia. Lancet 2, 924-926.

Jones, P, \& Murray, R. M. (1991) The genetics of schizophrenia is the genetic of neurodevelopment. Br. J. Psychiatry 158, 615-623.

Kaas, J. H., \& Anton, R. (1999) Evolutionary neurobiology: The neocortex comes together. Nature 399, 418-419.

Kety, S. S., Wender, P. H., Jacobsen, B., Ingraham, L. J., Jansson, L., Farber, B., \& Kinney, D. K. (1994) Mental illness in the biological and adoptive relatives of schizophrenia adoptees. Replication of the Copenhagen study in the rest of Denmark. Arch. Gen. Psychiatr 51, 442-455.

Klar, A. J., Baldassare, M., \& Jessel, T. M. (1992) F-spondin: a gene expressed at high levels in the floor plate encodes a secreted protein that promotes neural cell adhesion and neurite extension. Cell 69, 95-110.

Klintsova, A. Y., \& Greenough W. T. (1999) Synaptic plasticity in cortical system. Curr. Opin. Neurobiol. 9, 203-208.

Kuhl, D., \& Skehel, P. (1998) Dendritic localization of mRNAs. Curr. Opin. Neurobiol. 8, 600-608.

Kwon, Y. T., \& Tsai, L. H. (1998) A novel disruption of cortical development in p35 $(-/-)$ mice distinct from reeler. J. Comp. Neurol. 395, 510-522.

Kyte, J., \& Doolittle, R. F. A. (1982) A simple method for displaying the hydropathic character of a protein. J. Mol. Biol. 157, 105-142.

Lacor, P. N., Grayson, D. R., Auta, J., Sugaya, I., Costa, E., \& Guidotti, A. (2000) Reelin secretion from glutamatergic neurons in culture is independent from neurotransmitter regulation. Proc. Natl. Acad. Sci. USA 97, 3556-3561.

Lambert de Rouvroit, C. \& Goffinet A. A. (1998) The reeler mouse as a model of brain development. Adv. Anat. Embryol. Cell Biol. 150, $1-106$.

Liu, W. S., Pesold, C., Rodriguez, M. A., Carboni, G., Auta, J., Lacor, P, Larson, J, Condie, B. G., Guidotti, A., \& Costa, E. (2001) Downregulation of dendritic spine and glutamic acid decarboxylase 67 expression in the reelin haploinsufficient heterozygous reeler mouse. Proc. Natl., Acad. Sci. USA 98, 3477-3482.

Mainen Z. F. (1999) Functional plasticity at dendritic synapses. In Dendrites (G. Stuart, N. Spruston, and M. Häusser, Eds.), pp. 310-338. Oxford Univ. Press, New York.

Matus, A., \& Shepherd, G. M. (2000) The millennium of the dendrite? Neuron 27, 431-434. 
McCarley, R. W., Wible, C. G., Frumin, M., Hirayasu, Y., Levitt, J. J., Fischer, I. A., \& Shenton, M. E. (1999) Identification of neural circuits underlying P3000 abnormalities in schizophrenia. Psychophysiology 36, 388-98.

Mirnics, K., Mlddleton, F. A., Marquez, A., Lewis, D. A., \& Levitt, P. (2000) Molecular characterization of schizophrenia view of microarray analysis of gene expression in prefrontal cortex. Neuron 28, 53-57.

Miyashiro, K., Dichter, M., \& Eberwine, J. (1994) On the nature and differential distribution of mRNAs in hippocampal neurites: Implications for neuronal functioning. Proc. Natl. Acad. Sci. USA 91, 10800-10804.

Miyata, T., Nakajima, K., Mikoshiba, K., \& Ogawa, M. (1997) Regulation of Purkinje cell alignment by reelin is revealed with CR50 antibody. J. Neurosci. 17, 35599-35609.

Nieuwenhuys, R. (1994) The neocortex. An overview of its evolutionary development, structural organization, and synaptology. Anat. Embryol. 190, 307-337.

Nusser, Z. (1999) Subcellular distribution of neurotransmitter receptors and voltage-gated ion channels. In Dendrites (G. Stuart, N. Spruston, and M. Häusser, Eds.), pp. 85-113. Oxford Univ. Press, New York.

Ogawa, M., Miyata, T., Nakajima, K., Yagya, K., Seike, M., Ikenaka, K., Yamamoto, H., \& Mikoshiba, K. (1995) The reeler gene-associated antigen on Cajal-Retzius neurons is a crucial molecule for laminar organization of cortical neurons. Neuron 14, 899-912.

Pesold, C., Impagnatiello, F., Pisu, M. G., Uzunov, D. P., Costa, E., Guidotti, A., \& Caruncho, H. J. (1998) Reelin is preferentially expressed in neurons synthesizing $\gamma$-aminobutyric acid in cortex and hippocampus of adult rats. Proc. Natl. Acad. Sci. USA 95, 3221-3226.

Pesold, C., Liu, W. S., Guidotti, A., Costa, E., \& Caruncho, H. J. (1999a) A reelin haplo-insufficiency may underlie some of the neuroanatomical abnormalities found in schizophrenic brain. Soc. Neurosci. Abs. 25(1), 520.4, p. 1293.

Pesold, C., Liu, W. S., Guidotti, A., Costa, E., \& Caruncho, H. J. (1999b) Cortical bitufted, horizontal, and Martinotti cells preferentially express and secrete reelin into perineuronal nets, nonsynaptically modulating gene expression. Proc Natl. Acad. Sci. USA 96, 3217-3222.

Pesold, C., Rodriguez, V., Rodriguez, M., Liu, W. S., Guidotti, A., \& Costa, E. (2001) Reelin expression in the olfactory and motor system of the adult nonhuman primate brain. J. Neurosci., in preparation.

Pinkstaff, J. K., Detterich, J., Lynch, G., \& Gall, C. (1999) Integrin subunit expression is regionally differentiated in adult brain. J. Neurosci. 19, 1541-1546.

Purpura, D. P. (1975) Dendritic differentiation in human cerebral cortex: Normal and aberrant developmental patterns. Adv. Neurol. 12, 91-134.

Rakic, P., \& Caviness, Jr., V. S. (1995) Cortical development: View from neurological mutants two decades later. Neuron 14, 11011104.

Rakic, P. (1995a) Migration of neuronal clones in the developing cerebral cortex. Proc. Natl. Acad. Sci. USA 92, 11323-11327.

Rakic, P. (1995b) A small step for cell, a giant leap for mankind: A hypothesis of neocortical expansion during evolution. Trends Neurosci. 18, 383-388.

Ramon-Cajal, S. (1955) Histologie du Systeme Nerveus de l'Homme et des Vertebres. CSIC, Madrid.

Reynolds, G. P., Czudek, C., \& Andrew, H. B. (1990) Deficit and hemispheric asymmetry of GABA uptake sites in the hippocampus in schizophrenia. Biol. Psych. 27, 1038-1044.

Rice, D. S., \& Curran, T. (1999) Mutant mice with scrambled brains: Understanding the signaling pathways that control cell positioning in the CNS. Genes Dev. 13, 2758-2773.

Roberts, R. C., Conley, R., Kung, L., Peretti, J. F., Chute, D. J. (1996) Reduced striatal spine size in schizophrenia: A postmortem ultrastructural study. Neuroreport 7, 1214-1218.

Rodriguez, M. A., Pesold, C., Liu, W. S., Kriho, V., Guidotti, A., Pappas, G. D., \& Costa, E. (2000) Colocalization of integrin receptors and reelin in dendritic spine postsynaptic densities of adult nonhuman primate cortex. Proc. Natl. Acad. Sci. USA 97, 35503555.

Rosoklija, G., Toomayan, G., Ellis, S. P., Keilp, J., Mann, J. J., Latov, N., Hays, A. P., \& Dwork, A. J. (2000) Structural abnormalities of subicular dendrites in subjects with schizophrenia and mood disorders: Preliminary findings. Arch. Gen. Psychiatr. 57, 349-356.

Segal, M., Kozkotian, E., \& Murphy, D. D. (2000) Dendritic spine formation and pruning: Common cellular mechanisms? Trends Neurosci. 23, 53-57.

Selemon, L. D., \& Goldman-Rakic, P. S. (1999) The reduced neuropil hypothesis: A circuit-based model of schizophrenia. Biol. Psych. $45,17-25$.

Sheldon, M., Rice, D. S., D'Arcangelo, G., Yoneshima H., Nakajima K., Mikashiba K., Howell, B. W., Cooper, J. A., Goldowitz, D., \& Curran, T. (1997) Scrambler and yotari disrupt the disabled gene and produce a reeler-like phenotype in mice. Nature 389, 730-733.

Sherman, A. D., Davidson, A. T., Baruah, S., Hegwood, T. S., \& Waziri, R. (1991) Evidence of glutamatergic deficiency in schizophrenia. Neurosci. Lett. 121, 77-80.

Simpson, M. D., Slater, P., \& Deakin, J. F. (1998) Comparison of glutamate and Gamma-aminobutyric acid uptake binding sites in frontal and temporal lobes in schizophrenia. Biol. Psych. 44, 423427.

Siomi, H., Siomi, M. C., Nussbaum, R. L., \& Dreyfuss, G. (1993) The protein product of the fragile $X$ gene, FMR1, has characteristics of an RNA-binding protein. Cell 74, 291-298.

Smiley, J. F., Williams, S. M., Szigeti, K., Goldman-Rakic, P. S. (1992) Light and electron microscopic characterization of dopamineimmunoreactive axons in human cerebral cortex. J. Comp. Neurol. 321, 325-35.

Soghomonian, J. J., \& Martin, D. L. (1998) Two isoforms of glutamic acid decarboxylase: Why? Trends Pharmacol. Sci. 19, 500-505.

Somogyi, P., Tamas, G., Lujan, R., \& Buhl, E. H. (1998) Salient features of synaptic organization in the cerebral cortex. Brain Res. Brain Res. Rev. 26, 113-135.

Staubli, U., Chun, D., \& Lynch, G. (1998) Time-dependent reversal of long-term potentiation by an integrin antagonist. J. Neurosci. 18, 3460-3469.

Steward, O., Wallace, S., Lyford, G. L., \& Worley, P. F. (1998) Synaptic activation causes the mRNA for the IEG Arc to localize selectively near activated postsynaptic sites on dendrites. Neuron 21, 741-751.

Toni, N., Buchs, P. A., Nikonenko, I., Bron, C. R., \& Muller, D. (1999) LTP promotes formation of multiple spine synapses between a single axon terminal and a dendrite. Nature 402, 421-425.

Tueting, P., Costa, E., Dwivedi, J., Guidotti, A., Impagnatiello, F., Manev, R., \& Pesold, C. (1999) The phenotypic characteristics of heterozygous reeler mouse. Neuroreport 10, 1329-1334.

Uher, B. F., \& Golden, J. A. (2000) Neuronal migration defects of the cerebral cortex: a destination debacle. Clin. Genet. 58, 16-24.

Utsunomiya-Tate, N., Kubo, K., Tate, S., Kainosho, M., Katayama, 
E., Nakajima, K., \& Mikoshiba, K. (2000) Reelin molecules assemble together to form a large protein complex, which is inhibited by the function-blocking CR-50 antibody. Proc. Natl. Acad. Sci. USA 97, 9729-9734.

Volk, D. W., Austin, M. C., Pierri, J. N., Sampson, A. R., \& Lewis, D. A. (2000) Decreased glutamic and decarboxylase messenger RNA expression in a subset of prefrontal cortical $\gamma$-aminobutyric acid neurons in subjects with schizophrenia. Arch. Gen. Psychiatr. 57, 237-245.

Weiler, I. J., \& Greenough, W. T. (1993) Metabotropic glutamate receptors trigger postsynaptic protein synthesis. Proc. Natl. Acad. Sci. USA 90, 7168-7171.

Weiler, I. J., Irwin, S. A., Klintsova, A. Y., Spencer, C. M., Brazelton, A. D., Miyashiro, K., Comery, T. A., Patel, B., Eberwine, J., \& Greenough, W. T. (1997) Fragile X mental retardation protein is translated near synapses in response to neurotransmitter activation. Proc. Natl. Acad. Sci. USA 94, 5395-5400.

Weiler, I. J., Wang, X., \& Greenough, W. T. (1994) Synapse-activated protein synthesis as a possible mechanism of plastic neural change. Progr. Brain Res. 100, 189-194.

Weinberger, D. R., \& Lipska, B. K. (1995) Cortical maldevelopment, anti-psychotic drugs and schizophrenia: A search for common ground. Schizophren. Res. 16, 87-110.

Weinberger, D. R., Berman, K. F., \& Zec, R. F. (1986) Physiologic dysfunction of dorsolateral prefrontal cortex in schizophrenia. I: Regional control blood flow evidence. Arch. Gen. Psychiatr. 43, $114-124$.
Weinberger, D. R., Delisi, L. E., Perman, G. P., Targm, S., \& Wayatt, R. J. (1982) Computed tomography scans in schizophreniform disorders and other acute psychiatric patients. Arch. Gen. Psychiatr. 39, 778-783.

Wells, D. G., Richter, J. D., \& Fallon, J. R. (2000) Molecular mechanisms for activity-regulated protein synthesis in synapto-dendritic compartment. Curr. Opin. Neurobiol. 10, 132-137.

Woo, T. U., Whitehead, R. E., Melchitzky, D. S., \& Lewis, D. A. (1998) A subclass of prefrontal gamma-aminobutyric acid axon terminals are selectively altered in schizophrenia. Proc. Nat. Acad. Sci. USA 5341-5346.

Woods, B. T. (1998) Is schizophrenia a progressive neurodevelopmental disorder? Toward a unitary pathogenetic mechanism. Am. J. Psychiatr. 155, 1661-1670.

Xiao, P., Bahr, B. A., Staubli, U., Vanderklish, P. W., \& Lynch, G. (1991) Evidence that matrix recognition contributes to the stabilization but not the induction of LTP. NeuroReport 2, 461464.

Yagi, T., \& Takeichi, M. (2000) Cadherin superfamily genes: Functions, genomic organization, and neurological diversity. Genes Dev. 14, 1169-1180.

Yuste, R., Majewska, A., \& Holthoff, K. (2000) From form to function: Calcium compartmentalization in dendritic spines. Nature Neurosci. 3, 653-659.

Zec, N., \& Tieman, S. B. (1994) Development of the dendritic fields of layer 3 pyramidal cells in the kitten's visual cortex. J. Comp. Neurol. 339, 288-300. 